\title{
Analytical Study 2011 \\ Social security coverage of non-active persons moving to another Member State
}

\author{
Authors: \\ Filip VAN OVERMEIREN (ed.) \\ Eberhard EICHENHOFER \\ Herwig VERSCHUEREN
}

Organisation and Coordination of a Network on the Coordination of Social Security Schemes in the European Union

Lot 1: Expertise in Social Security Coordination

Project DG EMPL - VC/2010/0436

Contractor: Ghent University, Department of Social Law, Universiteitstraat 4, B-9000 Gent 


\section{Contents}

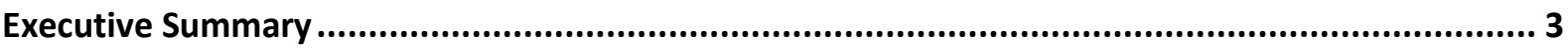

Introduction

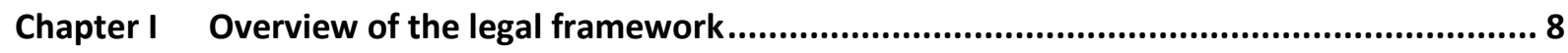

1. Residence rights of economically inactive EU citizens moving within the Union......................... 8

1.1 The right to free movement as a fundamental right ........................................................... 8

1.2 Conditions and limitations for economically inactive migrant persons in Directive 2004/38...... 8

2. Entitlement to "social assistance" for economically inactive migrant Union citizens in the host

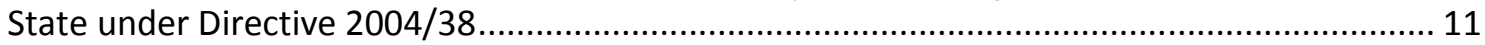

3. Entitlement to SNCBs and/or health care coverage for economically inactive migrants in the host Member State under Regulation 883/2004 ................................................................... 12

3.1 The objectives and principles of the EU coordination of social security systems ..................... 12

3.2 Special coordination systems for the so-called special non-contributory benefits (SNCBs) ...... 13

3.3 Access to health care in the host Member State for economically inactive migrant persons ... 15

4. The link between the entitlement to social benefits and health care coverage under Regulation $883 / 2004$ and the right to reside and to equal treatment under Directive 2004/38.................. 16

Chapter II A mapping of residence based social security systems in the Member States ............ 18

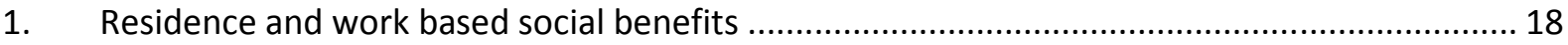

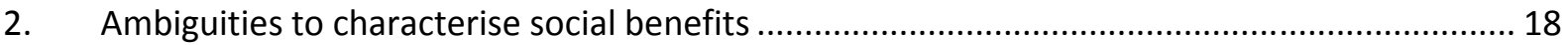

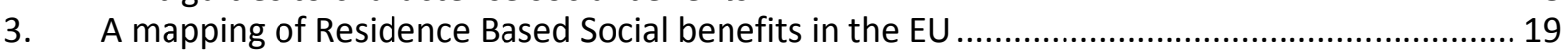

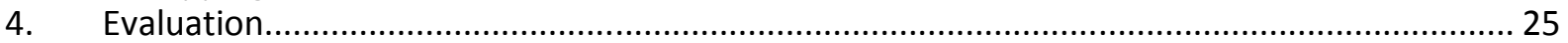

Chapter III Fact-finding on issues related to the coverage of non-active persons in the Member

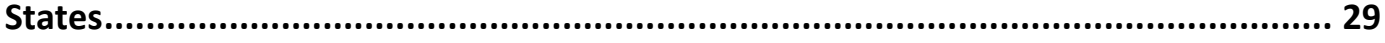

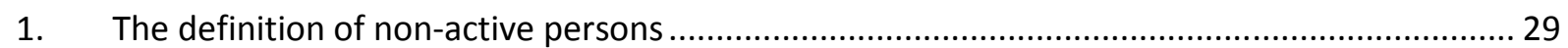

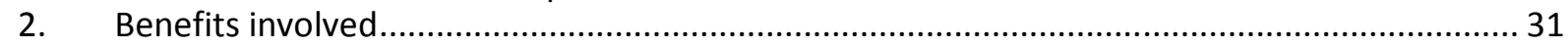

3. Fact-finding on the coverage of non-active persons in the Member States ............................ 32

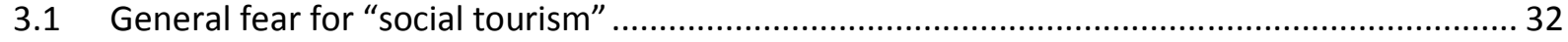

3.2 An increase in the number of claims from non-active persons .............................................. 33

3.3 The ambiguous relationship between Regulation 883/2004 and Directive 2004/38............... 35

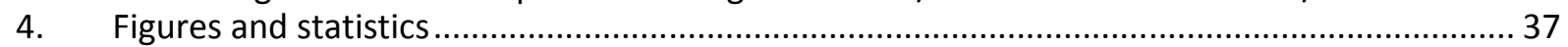

Chapter IV Evaluation and possible future perspectives......................................................... 42

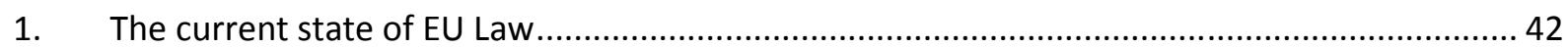

2. The Treaty-based right to equal treatment for all Union citizens and its limitations......................

Bladwijzer niet gedefinieerd.

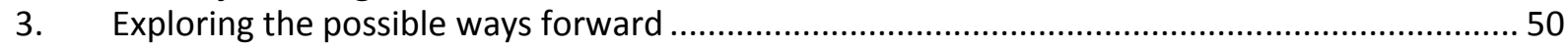

3.1 A better delineation between Regulation 883/2004 and Directive 2004/38 ........................... 50

3.2 Introducing a "flexible residence duration condition" in Regulation 883/2004 ....................... 50

3.3 Introducing a new "cost compensation mechanism" in Regulation 883/2004 ........................ 52

3.4 A better focus on the establishment of residence in a Member State...................................... 53 


\section{Executive Summary}

This ad hoc Analytic Study with regard to the transitional coverage of non-active persons moving to another Member State is the result of an analysis and evaluation of the replies of several EU Member States to a questionnaire from the European Commission. It can be situated as a contribution to the further acquisition of knowledge on the relationship between social security coordination Regulation 883/2004 and residence Directive 2004/38, which both the Commission and the Member States have deemed necessary.

In Chapter I, an overview of the relevant legal framework is provided. This contains an outline of the residence rights of economically inactive EU citizens moving within the European Union in Directive 2004/38, with special attention for the conditions and limitations to these rights. For a right of residence for more than three months, those rights are subject to the conditions of having sufficient resources and a comprehensive sickness insurance. Furthermore, their rights to social assistance under Directive 2004/38 and their rights to the so-called special non-contributory benefits (SNCBs) - special benefits with features of social security and social assistance - and health care coverage under Regulation 883/2004 are elucidated. Where the former instrument excludes an appeal to "social assistance" of a host Member State during the first three months of residence, the latter ensures access to certain residence based benefits (such as SNCBs and sickness benefits) as soon as a person has his factual centre of interest in that State.

To have a clear view on which benefits could be involved in this debate, Chapter II maps the residence based benefits in the EU Member States (cf. Tables 1-6). Despite the varying historical orientation of the social protection schemes of the Member States, their still differing welfare policy choices and the ambiguities to characterise social benefits, this mapping exercise clearly shows that residence based schemes can be detected in every Member State of the European Union, regardless of its institutional or programmatic orientation.

Chapter III turns to the concrete fact-finding on issues related to the coverage of nonactive persons in the Member States. From the replies of the responding Member States, some prudent conclusions can be drawn. Indeed, whereas some common notions on the definition of "non-active persons" can be found, a considerable amount of uncertainty remains among the Member States with regard to the exact contours of the category of 
non-active persons involved. As to the benefits involved, SNCBs and residence based health care clearly raise most concerns in the Member States. They are related to a general fear for "social tourism" and an increase in the number of claims from non-active persons. However, a general lack of elaborated case studies, figures and statistics impede a clear impact analysis or the detection of a trend with regard to these issues. From a legal point of view, a primordial concern has to do with the topical relationship between Regulation 883/2004 and Directive 2004/38.

Therefore, Chapter IV goes into the reported difficulties relating to the interdependence of these key instruments. In essence the arisen questions come down to a matter of priority: can a non-active person appeal to his coordination rights to social benefits under Regulation 883/2004 to fulfil the self-sufficiency condition of Directive $2004 / 38$ or should he, on the contrary, be legally resident first as envisaged in Directive 2004/38 before a right to residence based benefits coordinated by Regulation $883 / 2004$ can be acquired? Additionally, the latter option would mean that the limitations on the principle of equal treatment in Directive 2004/38 may limit the rights to SNCBs and to health care under Regulation 883/2004.

The analysis of both instruments learns that, from a legal point of view, there are no elements in the current state of EU law to establish that no provision of Directive 2004/38 would have any influence on the normal application of Regulation 883/2004. This application remains the same, in particular as to the interdependence between the right to SNCBs and to residence based sickness benefits on the one hand and the sufficient resources requirement and the comprehensive health insurance requirement on the other hand, respectively. Both instruments should thus be applied separately and in line with the Treaty obligations they represent.

Making the bridge to the relevant case law of the European Court of Justice (ECJ), it is apparent that EU law is sensitive to the Member States' desire for the establishment of a genuine link between a person claiming residence based non-contributory benefits and the Member State granting the benefit. However, in that regard the residence notion of Regulation 883/2004 was not only formally accepted as a solid basis for the entitlement to both SNCBs and residence based sickness benefits in a competent Member State, but also seems to be in line with the substantial requirements developed by the ECJ for the establishment of a genuine link with the host Member State for access to non-contributory benefits.

The current state of EU law nevertheless remains unsatisfactory as to the precise relationship between the concerned instruments, leaving too much room for different 
interpretations on the national level. It would thus be useful if the European legislator could anticipate possible further case law from the ECJ by providing the necessary clarification in this field. It is suggested that the ambivalent relationship between Regulation $883 / 2004$ and Directive $2004 / 38$ could be further clarified by:

- a safeguarding clause for Regulation $883 / 2004$ or a definition of social assistance in Directive 2004/38

- a waiting period in the residence concept of Regulation 883/2004 for the application of the special coordination regime for SNCBs

- a cost compensation mechanism between the former Member State of residence and the new State of residence for residence based benefits (SNCBs, sickness benefits) granted to non-active persons

- an enhanced focus on the assessment of the establishment of residence in the Member States in order to prevent confusion and cases of fraud and abuse and the introduction of an "abuse of rights" clause with regard to the residence concept in Regulation $883 / 2004$. 


\section{Introduction}

The analysis of the transitional coverage of non-active persons moving to another Member State is related to vital instruments of secondary Union law in the area of the free movement of persons, one of the cornerstones of the European Union. Directive 2004/38, which has repealed a bundle of older directives, was introduced to strengthen and simplify the exercise of the right to free movement and residence. Regulation 883/2004, in its turn replacing its predecessor Regulation 1408/71, was adopted to simplify and modernise the EU coordination system that guarantees that insured persons do not lose their social security protection when moving to another Member State. Although the essence of both domains of EU law has not changed in these latest versions, confusion has recently grown about their interdependence.

At the meeting of the Administrative Commission in October $2009,{ }^{1}$ an earlier $\operatorname{trESS}$ Think Tank report, presenting a general view on the relationship between these instruments, was discussed and in the same year the Commission published a communication ${ }^{2}$ providing further guidance on the application of Directive 2004/38. This topic remained the centre of interest during the Belgian Presidency in 2010, which lead to a note from the Secretariat ${ }^{3}$ and from the Presidency ${ }^{4}$ in the Administrative Commission in December 2010, clarifying the position of the Commission and the Member States respectively. The Commission made a clear distinction between the current legal situation on the one hand and the legitimacy of further discussion on possible future policy routes on the other hand. The Member States made clear that they were uncertain on how to apply both Regulation 883/2004 and Directive 2004/38, especially with regard to the different concepts of residence therein and to the relation between certain coordination rights and the conditions for legal residence set out in Directive 2004/38. Both agreed on the need for further analysis of this subject.

After the presentation in the Administrative Commission of a number of notes from the Member States on this topic, the Commission consequently decided to take concrete steps to further explore the subject and mandated the trESS Network with an ad hoc analytic study. This study was to be based on the replies from the Member States to a questionnaire that was presented to them in March 2011, ${ }^{5}$ expecting their responses by June 2011 . This report is the result of that analysis, providing an overview of the legal framework concerned, a mapping of residence based benefits in the Member States, a fact-finding analysis of the

\footnotetext{
CASSTM Note 403/09.

$\operatorname{COM}(2009) 313$.

CASSTM Note 419/10.

CASSTM Note $433 / 10$.

CASSTM Note 076/11.
} 
replies of the Member States and a legal evaluation with suggestions for future policy objectives.

In the meantime, the topic has been brought to a high political level. At the EPSCO Council of 17 June 2011, a joint statement of 13 Member States was added to the Council conclusions, in which they repeated that the concept of residence in the context of the interaction of the social security coordination Regulation 883/2004 with other relevant EU instruments, notably the free movement Directive 2004/38, should be further discussed. They called on all Member States and the European Commission to continue to look into this issue as a matter of priority. 


\section{Chapter I}

\section{Overview of the legal framework}

This chapter gives an overview of the currently applicable legal provisions which may be relevant for the discussion on the issue of residence rights as well as the right to social benefits for economically inactive persons moving within the EU. It will concentrate on the provisions of Directive 2004/38 as well as on those of Regulation 883/2004 and on the interference between these instruments.

\section{Residence rights of economically inactive EU citizens moving within the Union}

\subsection{The right to free movement as a fundamental right}

The right for Union citizens to move and reside freely within the territory of the Member States is enshrined in both the TFEU (Article 21) and in the Charter of Fundamental Rights of the EU (Article 45; hereinafter the "Charter"). This right is irrespective of the exercise by the Union citizen of an economic activity. The Court of Justice (ECJ) has recognised the direct effect of Article $21 \mathrm{TFEU}$, thus confirming that this right is conferred directly on every citizen of the Union by a clear and precise provision of the Treaty. ${ }^{6}$ The ECJ also observed that citizenship of the Union confers on each citizen a primary and individual right to move and reside freely within the territory of the Member States, subject to the limitations and restrictions laid down by Union law. Yet, limitations and conditions laid down in EU law must be interpreted restrictively and must be applied in accordance with the principle of proportionality. ${ }^{7}$ According to the ECJ provisions laying down a fundamental principle such as that of the free movement of persons must be interpreted broadly. ${ }^{8}$

\subsection{Conditions and limitations for economically inactive migrant persons in Directive 2004/38}

Directive $2004 / 38^{9}$ specifies the residence ${ }^{10}$ rights of moving Union citizens (and the members of their families) and defines some conditions and limitations. It aims to facilitate the free movement of Union citizens and in particular to simplify and strengthen that right

Case C-413/99 Baumbast ECR [2002] I-7091, para 84 et seq.

Case C-162/09 Lassal [2010] nyr, paras 29-31. See also Case C-413/99 Baumbast ECR [2002] I-7091, para 91.

8 See inter alia Case C-200/02 Zhu and Chen [2004] I-9925, para 31 and Case C-408/03 Commission v. Belgium [2006] I-2647, para 40.

9 Directive 2004/38/EC of the European Parliament and of the Council of 29 April 2004 on the right of citizens of the Union and their family members to move and reside freely within the territory of the Member States. See on this Directive the Communication from the Commission on guidance for better transposition and application of Directive 2004/38/EC of 2 July 2009, COM(2009) 313.

10 Directive 2004/38 does not provide any definition of the concept of residence. It seems to cover both temporary stay as well as habitual residence in the host Member State. 
(recital 3). Among other things, the ECJ confirmed that Union citizens cannot derive fewer rights from that directive than from the instruments of secondary legislation which it amends or repeals. ${ }^{11}$

Directive 2004/38 grants the right of residence for up to three months to all Union citizens without any conditions or any formalities other than the requirement to hold a valid identity card or passport (Article 6(1), Directive 2004/38). Nevertheless, Article 14(1) of Directive 2004/38 guarantees the retention of the right of residence provided for in Article 6 to Union citizens only as long as they do not become an unreasonable burden on the social assistance system of the host Member State.

The right of residence for more than three months for economically inactive persons is on condition that they have sufficient resources for themselves and their family members so as not to become a burden on the social assistance system of the host Member State, as well as on the condition that they have comprehensive sickness insurance (Article $7(1)(b) \&(c)$, Directive 2004/38).

These conditions regarding sufficient resources and comprehensive sickness insurance neither apply to workers and self-employed persons, nor to persons who stopped being economically active but who do retain this status pursuant to Article 7(3) of Directive $2004 / 38 .{ }^{12}$ Nor do they apply to jobseekers who entered the territory of the host Member State in order to seek employment. Such persons may not be expelled for as long as they can provide evidence that they are continuing to seek employment and that they have a genuine chance of being engaged (Article 14(4)(b), Directive 2004/38). Their right of residence does not depend on them having sufficient resources or comprehensive sickness insurance. The residence rights of economically active persons and persons considered as such follow directly from the Treaty provisions on the free movement of workers and of service providers (Articles 45 and 49 TFEU).

Article 14(2) of Directive 2004/38 limits the residence right to Union citizens and their family members as long as they meet the conditions set out in Article 7, which for economically inactive persons means having sufficient resources and comprehensive sickness insurance. It continues by stating that in specific cases where there is reasonable doubt as to whether a Union citizen or his or her family members satisfies the conditions set out in Article 7, including the conditions on sufficient resources and health care coverage, Member States may verify if these conditions are fulfilled. However, this verification shall not be carried out

11 Case C-162/09 Lassal [2010] nyr, para 30. See also Case C-127/08 Metock and Others [2008] ECR I-6241, paragraphs 82 and 59.

12 Pursuant to Article 7 (3) Directive 2004/38 an EU citizen maintains his status as an employee or selfemployed person in certain circumstances, i.e. if he or she is temporarily unable to work as the result of an illness or accident or is in duly recorded involuntary unemployment or embarks on vocational training. 
systematically. Furthermore, Article $14(3)$ of Directive 2004/38 provides that an expulsion measure shall not be the automatic consequence of a Union citizen's or his or her family members' recourse to the social assistance system of the host Member State. In the Commission's view, this provision means that "as long as the beneficiaries of the right of residence do not become an unreasonable burden on the social assistance system of the host Member State, they cannot be expelled for this reason" ${ }^{13}$

For the assessment of the unreasonableness, recital 16 of Directive 2004/38 specifies that the host Member State should examine whether it is a case of temporary difficulties and take into account the duration of residence, the personal circumstances and the amount of aid granted in order to consider whether the beneficiary has become an unreasonable burden on its social assistance system and to proceed to his or her expulsion. ${ }^{14}$

In its case law, the ECJ confirmed that the origin of a person's resources is not relevant to assess the fulfilment of the resources requirement in the residence directives. ${ }^{15}$

After five years of legal residence, a Union citizen and the members of his or her family obtain the right of permanent residence (Article 16, Directive 2004/38). ${ }^{16}$ This right of permanent residence does not depend on being economically active or having sufficient resources and comprehensive sickness insurance.

Recently the ECJ also recognised that Directive $2004 / 38$ is not the only secondary law instrument that may grant migrating Union citizens a right to reside. In Ibrahim and Teixeira $^{17}$ the ECJ confirmed that, pursuant to Article 12 of Regulation 1612/68, ${ }^{18}$ the children of an EU citizen who have settled in a Member State during the exercise by their parent(s) of rights of residence as a migrant worker in that Member State are entitled to reside there in order to attend general educational courses. The fact that the parents of the children concerned have meanwhile divorced and the fact that the parent who exercised rights of residence as a migrant worker is no longer economically active in the host Member State and even does not possess sufficient means of subsistence are irrelevant in this regard. It is sufficient that the child settled in the Member State concerned at the time that one of

COM 2009(313) p. 9.

14 See on this issue also the Commission's Communication of 2 July 2009, $\operatorname{COM(313),~p.~8-9.~}$

15 Case C-200/02 Zhu and Chen [2004] I-9925, para 30-31 and Case C-408/03 Commission v. Belgium [2006] I2647, para 40.

16 Pursuant to Article 17 of Directive 2004/38, this right of permanent residence can even be enjoyed before the completion of five years of residence for certain categories of persons.

17 Case C-310/08, Ibrahim, [2010] nyr and Case C-480/08, Teixeira, [2010] nyr.

18 Regulation (EEC) 1612/68 of the Council of 15 October 1968 on freedom of movement for workers within the Community. This Regulation has recently been replaced by Regulation (EU) 492/2011 of the EP and the Council of 4 April 2011. However, this new regulation does not alter the provisions of the former but only codifies them. 
the parents resided there as a migrant worker. The ECJ also ruled that, as a consequence of the children's right to reside, the parents who are their carers must be allowed to remain in the host Member State during the period of their children's education. ${ }^{19}$ The ECJ did explicitly not accept that Directive 2004/38 would have made the application of the provisions of Regulation 1612/68 subject to compliance with the conditions for residence set out in Directive 2004/38. In the ECJ's view this would mean that the provisions of Regulation $1612 / 68$ are interpreted restrictively and rendered ineffective, which is not acceptable. ${ }^{20}$ Restricting the provisions of another EU secondary law instrument would only be possible by an explicit decision of the EU legislature, which was not the case here.

2. Entitlement to "social assistance" for economically inactive migrant Union citizens in the host State under Directive 2004/38

One of the basic principles of Union law is the prohibition of discrimination on grounds of nationality. This principle is laid down in Article 18 TFEU in general and in Article 45 TFEU in particular for workers and jobseekers. In its case law prior to the adoption of Directive 2004/38 the ECJ confirmed that this principle applies to social minimum benefits. However, the ECJ did not allow economically inactive migrants unconditional access to welfare benefits of the host State. Legal residence in the host State is the first condition to be fulfilled by the applicant. ${ }^{21}$ In addition and depending on the case, he or she should "not become an unreasonable burden on the public finances" 22 ; "have a genuine link with the employment market of the State concerned" ${ }^{23}$ or "need to demonstrate a certain degree of integration into the society of the host State". ${ }^{24}$ So, the ECJ accepts possible justifications for derogations to equal treatment for social minimum benefits provided that the proportionality test is met.

This case law is reflected in Directive 2004/38. Article 24(1) of Directive 2004/38 guarantees all Union citizens residing on the basis of this directive in the territory of the host Member State equal treatment with the nationals of that Member State within the scope of the Treaty.

However, as regards social assistance, Article 24(2) of Directive 2004/38 stipulates that the host Member State shall not be obliged to confer entitlement to social assistance during the first three months of residence or, where appropriate, during the longer period provided for

\footnotetext{
19 See already in Case C-483/99, Baumbast [2002] ECR I-7091.

20 Case C-480/08, Teixeira, [2010] nyr, para 60 and 67.

21 Case C-456/02, Trojani [2004] ECR I-7573, para 43.

22 Case C-184/99, Grzelczyk [2001] ECR I-6193, para 44.

23 Case C-138/02, Collins [2004] ECR I-2703, para, 67-69.

24 Case C-209/03, Bidar [2005] ECR I-2119, para 57.
} 
in Article 14(4)(b). The latter provision refers to Union citizens who entered the territory of the host Member State in order to seek employment. Such persons may not be expelled for as long as they can provide evidence that they are continuing to seek employment and that they have a genuine chance of being engaged. However, the ECJ has interpreted Article 45 TFEU in such a way that a minimum subsistence allowance for jobseekers meant to facilitate access to employment in the labour market of a Member State cannot be regarded as "social assistance" within the meaning of Article 24(2) of Directive 2004/38. For the ECJ it would have to be granted to a person who has a genuine link with the employment market of the host State - which may be established through residence for a reasonable period and the fact that the person has genuinely sought work in that State. ${ }^{25}$

Prior to the acquisition of the right of permanent residence, the host Member State shall not be obliged either to grant maintenance aid for studies, including vocational training, consisting in student grants or student loans to persons other than workers, self-employed persons, persons who retain this status and members of their families.

3. Entitlement to SNCBs and/or health care coverage for economically inactive migrants in the host Member State under Regulation 883/2004

\subsection{The objectives and principles of the EU coordination of social security systems}

The EU coordination of social security systems is designed to lift obstacles to the free movement of persons following from the diversity of the social security systems of the Member States. The system put in place is merely a system of coordination. It does not seek to harmonise the Member States' systems or to bring them closer together. The only objective is to coordinate them in such a way that the negative effects the differences between those systems may have for migrant persons are removed.

Fulfilling the mandate of Article 48 TFEU, the EU legislator adopted an elaborate system of coordination of the Member States' social security schemes. Until 1 May 2010 this was laid down in Regulation $1408 / 71^{26}$ and Regulation $574 / 72^{27}$ and from this date in Regulation $883 / 2004^{28}$ and Regulation 987/2009. ${ }^{29}$

25 Cases C-22/08 and C-23/08, Vatsouras and Koupatantze [2009] ECR I-4585, para 36-37. See also: Case C138/02, Collins [2004] ECR I-2703, para 56; Case C-258/04, loannidis [2005] ECR I-8275, para 30.

26 Regulation (EEC) 1408/71 of 14 June 1971 concerning the application of the social security schemes to employees and self-employed persons, as well as to their family members travelling within the Community.

27 Regulation (EEC) 574/72 of 21 March 1972 laying down the procedure for implementing Regulation (EEC) $1408 / 71$.

28 Regulation (EC) 883/2004 of 29 April 2004 on the coordination of social security systems.

29 Regulation (EC) 987/2009 of 16 September 2009 laying down the procedure for implementing Regulation (EC) $883 / 2004$. 
In the first place, this coordination regime determines which Member State's social security legislation applies in a cross-border situation (Title II of Regulation 883/2004). These rules on the determination of the applicable legislation are based on the State of employment principle for economically active persons and the State of residence principle for economically inactive persons. This is intended to prevent that the application of the legislation of the Member States would lead to double affiliation to the social security systems of the Member States, or to the absence of affiliation as a result of which migrant persons would fall between two stools.

Another underlying principle of this coordination is that of the prohibition of discrimination on grounds of nationality (Article 4, Regulation 883/2004). In addition, the coordination also contains rules with regard to the waiving of residence clauses in the allocation or preservation of social security benefits (Article 7 Regulation 883/2004). It also establishes a number of rules with regard to the aggregation of periods of insurance, employment and residence (Article 6 Regulation 883/2004).

Economically inactive persons can also be covered by this EU coordination system. Indeed, Regulation 883/2004 refers in the definition of its personal scope to all nationals of a Member State who are or have been subject to the legislation of one or more Member States (Article 2, Regulation 883/2004), without referring to the status of employed or selfemployed person (as was the case in Article 2, Regulation 1408/71).

\subsection{Special coordination systems for the so-called special non-contributory benefits} (SNCBs)

This coordination system is applicable to the different branches of social security ${ }^{30}$, but it excludes "social and medical assistance" ${ }^{31}$ (see Article 3, Regulation 883/2004).

30 The different social security branches were summed up in Article 3 of Regulation 883/2004. The benefits are related to the classic social risks. These are maternity or paternity, sickness, invalidity, old age, accidents at work, occupational disease, death, unemployment, pre-retirement and family maintenance obligations. To qualify a given branch of social protection of a Member State in the light of EU law as social security, it does not matter whether the benefits are enshrined in a general or a special scheme, are financed out of taxes or contributions or the administration is based on public or private law.

31 Social and medical assistance are mentioned in Article 3(5) of Regulation 883/2004, but no definition of such benefits is provided. The distinction between social security and social assistance rests entirely on the factors relating to each benefit, in particular its purpose and the conditions for its grant. Case 249/83, Hoeckx [1985] ECR I-973, para 11 and Case 122/84, Scrivner and Cole [1985] ECR I-1027, para 18. Especially in the current state of welfare organisation, in which social security and social assistance have grown towards each other, such a general distinction becomes more difficult. 
However, the ECJ has developed a broad definition of social security within the meaning of these regulations. Confronted with claims to export a number of minimum subsistence benefits, the ECJ had to rule on the question whether they fall under the notion of social assistance and are therefore excluded from the scope of this coordination system and its principle of export of benefits. This discussion concerned benefits that were called "special non-contributory benefits of a mixed kind" since they were halfway between traditional social security and social assistance, falling simultaneously within both categories. Examples of such benefits are supplements to pensions and special benefits for disabled persons. In its case law of the 1970s and 80s, the ECJ developed a broad definition of social security including these special non-contributory benefits (SNCBs) to which the ECJ applied the export provision. ${ }^{32}$

In response to this case law, the EU legislature intervened in 1992 by creating a special coordination system for these benefits. ${ }^{33}$ For the benefits listed in the newly created Annex Ila of Regulation 1408/71, Member States could apply a residence condition preventing the export of these benefits. As a consequence, a beneficiary of such a benefit would, on the one hand, lose it when transferring his or her residence to another Member State and would, on the other, be entitled in his new Member State of residence to benefits of that state listed in Annex Ila. This entitlement in the new Member State of residence was clearly the price the Member States wanted to pay to avoid the obligation to export these benefits as imposed by the case law of the ECJ. The ECJ endorsed this agreement in principle, ${ }^{34}$ but was very critical of the qualification of some specific benefits as SNCBs. ${ }^{35}$

Regulation 883/2004 took over this special coordination regime for a number of such benefits listed in its Annex X (see Article 70, Regulation 883/2004). This means that persons falling under the scope of this regulation are entitled to the SNCBs included in this list in the Member State where they reside. The only requirement for entitlement to these benefits is residence defined in Article $1(\mathrm{j})$ of Regulation 883/2004 as being the place where a person habitually resides. This definition is further specified in Article 11 of Regulation 987/2009 as being the centre of interests of the person concerned, based on an overall assessment of all available information relating to relevant facts. These may include the duration and

32 See for instance Case 1/72, Frilli [1972] ECR 457 (on the Belgian "Guaranteed income for old people"); Case 187/73, Callemeyn [1974] ECR 553 (on the Belgian "Benefits to handicapped persons"); Case 63/76, Inzirillo [1976] ECR 2057 (on the French "Allowance for handicapped adults"); Case 139/82, Piscitello [1983] ECR 1427 (on the Italian "Social aid pensions"); Joined Cases 379-381/85 and 93/86, Giletti and others [1987] ECR 955 (on the French "Supplementary allowance" paid to the recipients of old-age, survivor's and invalidity pensions by the national solidarity fund); Case C-356/89, Newton [1991] ECR 3017 (on the UK "Mobility allowance" for the disabled). By Regulation (EEC) No 1247/92 of the Council of 30 April 1992.

34 See for instance Case C-20/96, Snares [1997] ECR I-6057; Case C-297/96, Partridge [1998] ECR I-3467; Case C-160/02, Skalka [2004] ECR I-5613; Case C-154/05, Kersbergen-Lap [2006] ECR I-6249.

35 See for instance Case C-43/99, Leclere [2001] ECR I-4265; Case C-215/99, Jauch [2001] ECR I-1901; Case C299/05, Commission v. European Parliament and Council ECR [2007] ECR I-8695. 
continuity of presence on the territory of the Member States concerned and the person's situation, including inter alia his family status and family ties, the exercise of any nonremunerated activities, his housing situation, in particular how permanent it is, and the Member State in which the person is deemed to reside for taxation purposes. If these elements do not produce a solution, the person's intention, as it appears from such facts and circumstances, especially the reasons that led the person to move, shall be considered to be decisive to establish that person's actual place of residence. This provision adopts an EU wide definition of the concept of residence for the implementation of Regulation 883/2004, including this special coordination regime for the SNCBs listed in Annex X. It therefore sets aside nationally defined concepts of residence. ${ }^{36}$ It is also clear that the concept of residence so defined is more restricted than the concept of residence used in Directive 2004/38, which encompasses both temporary stay and habitual residence.

This residence condition was apparently considered by the EU legislature as creating a genuine link between the claimant and the host Member State for the entitlement to the SNCBs listed in Annex X. For non-contributory benefits in cases falling outside the scope of the EU social security coordination, the ECJ has indeed recognised that Member States may require the existence of such a link. ${ }^{37}$ In a case on an exportable non-contributory benefit falling within the scope of Regulation 1408/71 the ECJ also acknowledged that it can be considered to be legitimate for a Member State to award such a benefit only after it has been established that there was a genuine link between the claimant and the competent State. ${ }^{38}$ Yet, as far as the non-exportable special non-contributory benefits listed in Annex Ila of Regulation 1408/71 were concerned, the ECJ clarified that the benefit entitlement which is conditional on the claimant's residence in the competent State, is not conditional on the claimant previously having been subject to the social security legislation of the State in which he applies for the benefit. ${ }^{39}$ Thus, we may conclude that for these non-exportable SNCBs residence on the territory of the competent State seems to be accepted both by the EU legislature and by the ECJ as creating a genuine link between the claimant and that State.

\subsection{Access to health care in the host Member State for economically inactive migrant persons}

In principle, economically inactive persons are subject to the legislation of the Member State of residence (Article 11(3)(e), Regulation 883/2004). This includes the right to equal treatment with the citizens of this host State, including health care coverage. However,

\footnotetext{
36 See on the need to have such an EU wide definition: Case C-90/97, Swaddling [1999] ECR I-1075.

37 See for instance: Case C-184/99 Grzelczyk [2001] ECR I-6193; Case C-138/02 Collins [2004] ECR I-2703; Case C-209/03 Bidar [2005] ECR I-2119; Case C-192/05 Tas-Hagen and Tas [2006] ECR I-10451; Case C-158/07 Förster [2008] ECR I-8507.

38 Case C-503/09, Stewart, nyr, para 92.

39 Case C-20/96 Snares [1997] I-6057, para 48.
} 
pursuant to specific rules in the sickness benefits chapter of Regulation 883/2004 (Articles 17-35) in a number of situations the access to health care in the host State is at the expense of another State, even for economically inactive migrants. This is in the first place the case for migrants who are only temporarily staying in the host Member State while continuing to be covered by the health insurance of their home State (which for that purpose issued a European Health Insurance Card - EHIC). This may also be the case for migrant persons habitually residing in the host State, such as pensioners only drawing a pension from another State. The latter State will reimburse, according to specific provisions agreed in this respect, the costs of the treatment for these pensioners.

However, the host State may not always be able to claim reimbursement of the costs for health care delivered to economically inactive migrants from another Member State. In such situations, the equal treatment provision of Article 4 of Regulation 884/2004 guarantees such persons entitlement to health coverage under the same conditions as the nationals of the host State resident in that State ${ }^{40}$.

4. The link between the entitlement to social benefits and health care coverage under Regulation 883/2004 and the right to reside and to equal treatment under Directive 2004/38

We explained above that under Directive 2004/38 the right to reside in the host Member State for economically inactive persons is dependent on them having sufficient resources and a comprehensive sickness insurance (unless the person has obtained a right to permanent residence). Yet, expulsion measures depend on the unreasonableness of the reliance on the social assistance systems of the host Member State.

Entitlement to a social benefit or to health care coverage on the basis of Regulation $883 / 2004$ may help the economically inactive migrant person to fulfil these requirements. This is certainly true in case of export of benefits such as pensions and health care coverage on behalf of another Member State than the host State.

We also explained that as a result of the provisions agreed by the EU legislature in Regulation $883 / 2004$, economically inactive migrant persons may also be entitled to special non-contributory benefits as well as health coverage in the Member State of residence.

\footnotetext{
${ }^{40}$ For an extensice overview of the legal position of uninsured persons, see the trESS Think Tank Report (2010), „Healthcare provided during a temporary stay in another Member State to persons who do not fulfil conditions for statutory health insurance coverage", http://www.tress-network.org/
} 
Questions are raised on whether the limitations on the principle of equal treatment in Article 24(2) of Directive 2004/38 in respect of social assistance may limit the rights to SNCBs and to health care under Regulation 883/2004. In addition, the question is raised whether persons wanting to invoke Regulation 883/2004 in order to claim SNCBs or health coverage in the Member State in which they reside, put their right of residence at stake, because they no longer fulfil the requirements with regard to a right to reside in the host State under Directive 2004/38. These questions are further dealt with in Chapter III, point 3.3 and Chapter IV, point 1. 


\section{Chapter II}

\section{A mapping of residence based social security systems in the Member States}

\section{Residence and work based social benefits}

Social benefits depend on the residence or the workplace of the beneficiary in a given Member State. This difference characterises both the various programmes and the different institutions of social protection. As to their programme, benefits can traditionally be considered as of the Beveridge or the Bismarck type. The first is addressed to residents; it provides flat rate benefits in cash and is financed out of taxes. The latter is addressed to the economically active persons, the benefits in cash are income-related and they are financed out of contributions. As to the institutional setting, social benefits can be considered as social assistance and social insurance schemes. Whereas the former are means tested and needs related, the latter are risk-related and cash benefits are often proportional to the earned income. It must however be noted that, over the years, Bismarck and Beveridge oriented systems on the one hand and social security and social assistance systems on the other hand, have grown towards each other considerably. These traditional distinctions are not easily made nowadays.

In a given system of social protection, each Member State has a free choice on both the programme and the institutions of social protection. The Member States have made and still make different choices as to their welfare systems and their priorities. Due to this, the social protection schemes of the Member States vary substantially.

\section{Ambiguities to characterise social benefits}

Social assistance and social security benefits of the Beveridge type and social insurance and social security of the Bismarck type have some similarities, but they are not identical. On the contrary, they are profoundly different in both objective and scope: social assistance is a subsidiary institution, as it meets the needs of a minority, whereas social security benefits of the Beveridge or Bismarck type are either universal or addressed to the working population at large.

Within the distinctions made by Regulation 883/2004, what is generally regarded as "social assistance" from a national perspective can be excluded from or included in the material scope of the regulation. This depends on whether the benefit is to be qualified as an SNCB or not. Medical help can be given on the basis of medical assistance or in the context of a universal health care system. In the latter case it is to be qualified as social security. 
From this follows that if it comes to the analysis of the social protection provided by the various Member States, a broad view is needed as to whether the benefits can be conceived as social or medical assistance or can be characterised as social security or SNCB. In this broad understanding a social benefit can be taken into account as a potential social assistance benefit, as long as it intends to meet elementary needs of the individual. This function can be fulfilled by benefits, which can be qualified as social security, SNCB or social assistance benefits in a strict legal sense.

\section{A mapping of Residence Based Social benefits in the EU}

When mapping ${ }^{41}$ the social benefits of the 27 EU Member States in this context, they should be subdivided according to their different legal status within the framework of Regulation $883 / 2004$ as social security, SNCB or as social assistance. The broad and abstract overview will be differentiated as to the various social risks, as they are listed in Art. 3: health care (a), income protection in cases of sickness and mother or fatherhood (b), invalidity and disability (c), old age and death (d), unemployment (e) and family benefits (f). The benefits for work accidents and professional diseases will not be dealt with, as they mature from paid work. They are not important in the context of this inquiry, which is addressed to social entitlements to the economically inactive population.

The Member States will be abbreviated as follows: Austria AT, Belgium BE, Bulgaria BG, Czech Republic CZ, Cyprus CY, Denmark DK, Estonia ES, Finland FI, France FR, Germany GE, Greece GR, Hungary HU, Ireland IR, Italy IT, Latvia LV, Lithuania LT, Luxembourg LU; Malta MT, The Netherlands NL, Poland PL, Portugal PT, Romania RO; Slovakia SK; Slovenia SL, Spain SP, Sweden SW and the United Kingdom UK.

41 The main information source for this mapping exercise was the website of MISSOC, http://missoc.org/ 


\section{a) Sickness Benefits in Kind (Table 1)}

Abbreviations: $\mathrm{I}=$ health insurance; $\mathrm{S}=$ health service; $\mathrm{m}$. $\mathrm{a} .=$ medical aid; $\mathrm{f}$. h. c. $=$ free health care

\begin{tabular}{|l|l|}
\hline & Soc. Sec. \\
\hline AT & I \\
\hline BE & I \\
\hline BG & I \\
\hline CZ & S \\
\hline CY & S \\
\hline DK & S \\
\hline ES & S \\
\hline FI & S \\
\hline FR & I \\
\hline GE & I \\
\hline GR & I \\
\hline HU & I \\
\hline IR & S \\
\hline IT & S \\
\hline LV & S \\
\hline LT & S \\
\hline LU & I \\
\hline MT & S \\
\hline NL & I \\
\hline PL & I \\
\hline PT & S \\
\hline RO & I \\
\hline SK & I \\
\hline SL & I \\
\hline SP & S \\
\hline SW & S \\
\hline UK & S \\
\hline & \\
\hline
\end{tabular}




\section{b) Sickness Benefits in Cash and Maternity/Paternity Benefits (Table 2)}

Abbreviations: $\mathrm{I}$ = insurance; $\mathrm{A}=$ Allowance; $\mathrm{W}=$ wage; - = nothing

\begin{tabular}{|l|l|l|}
\hline & Soc. Sec. (sickn.) & Soc. Sec. (mat.) \\
\hline AT & W/I & I \\
\hline BE & W/I & I \\
\hline BG & W/I & W/I \\
\hline CZ & I & I \\
\hline CY & & A \\
\hline DK & W/I & A \\
\hline ES & I & I \\
\hline FI & W/I & A \\
\hline FR & W/I & I \\
\hline GE & W/I & I/A \\
\hline GR & W/I & I \\
\hline HU & W/I & I \\
\hline IR & I & I \\
\hline IT & W/I & I \\
\hline LV & W/I & I \\
\hline LT & W & I/A \\
\hline LU & I & I \\
\hline MT & W/I & W/A \\
\hline NL & W/I & - \\
\hline PL & W/I & - \\
\hline PT & I & I \\
\hline RO & I & I \\
\hline SK & W/I & I \\
\hline SL & W/I & A \\
\hline SP & W/I & W/A \\
\hline SW & W/I & \\
\hline UK & W & W \\
\hline & & W \\
\hline
\end{tabular}




\section{c) Invalidity and Disability Benefits (Table 3)}

Abbreviations: $\mathrm{PI}=$ Pension Insurance; $\mathrm{SI}=$ Social Insurance; $\mathrm{OB}=$ own branch; $\mathrm{WA}=$ work accident;

$\mathrm{FB}=$ Family Benefit; $\mathrm{BP}=$ Basic Pension; $\mathrm{HI}=$ Health Insurance; $\mathrm{LP}=$ Labour Market Programme

\begin{tabular}{|c|c|c|c|}
\hline & $\begin{array}{l}\text { Soc.Sec. } \\
\text { (inval.) }\end{array}$ & $\begin{array}{l}\text { Soc. Sec. } \\
\text { (disab.) }\end{array}$ & SNCB \\
\hline AT & $\mathrm{PI}$ & $\mathrm{SI}, \mathrm{FB}$ & \\
\hline $\mathrm{BE}$ & $\mathrm{HI}$ & WA, FB & \\
\hline BG & $\mathrm{SI}$ & $\mathrm{SI}$ & \\
\hline $\mathrm{CZ}$ & $\mathrm{PI}$ & $\mathrm{PI}$ & Social Allowance \\
\hline $\mathrm{CY}$ & $\mathrm{SI}$ & $\mathrm{SI}$ & $\begin{array}{l}\text { Disability Allowance } \\
\text { Grants to blind persons }\end{array}$ \\
\hline DK & BP & LP & \\
\hline ES & $\mathrm{PI}$ & $\mathrm{PI}, \mathrm{FB}$ & Disabled Adult Allowance \\
\hline $\mathrm{FI}$ & BP & LP & Housing Allowance \\
\hline FR & $\mathrm{HI}$ & $\mathrm{HI}, \mathrm{FB}$ & $\begin{array}{l}\text { Special Invalidity Fund } \\
\text { Disabled Adult Allowance }\end{array}$ \\
\hline GE & $\mathrm{PI}$ & $\mathrm{SI}$ & Basis Substitution Income \\
\hline GR & $\mathrm{PI}$ & $\mathrm{PI}, \mathrm{FB}$ & \\
\hline $\mathrm{HU}$ & $\mathrm{PI}$ & $\mathrm{PI}$ & $\begin{array}{l}\text { Invalidity Annuity } \\
\text { Transport allowance }\end{array}$ \\
\hline IR & $\mathrm{SI}$ & $\mathrm{SI}$ & $\begin{array}{l}\text { Supplementary Welfare } \\
\text { Blind Pension } \\
\text { Disability Mobility Allowance } \\
\end{array}$ \\
\hline IT & $\mathrm{PI}$ & $\mathrm{SI}, \mathrm{WA}, \mathrm{FB}$ & $\begin{array}{l}\text { Pensions and allowances for disabled and } \\
\text { deaf persons } \\
\text { Supplements }\end{array}$ \\
\hline LV & $\mathrm{PI}$ & $\mathrm{PI}$ & Allowance for the Disabled \\
\hline $\mathrm{LT}$ & $\mathrm{PI}$ & $\mathrm{PI}$ & Mobility Allowance \\
\hline LU & $\mathrm{PI}$ & $\mathrm{PI}$ & Seriously Disabled Income \\
\hline MT & $\mathrm{SI}$ & $\mathrm{SI}$ & Supplementary Income \\
\hline $\mathrm{NL}$ & OB & $\mathrm{HI}, \mathrm{FB}$ & Allowance for Young Handicapped Persons \\
\hline $\mathrm{PL}$ & $\mathrm{PI}$ & $\mathrm{PI}$ & \\
\hline PT & $\mathrm{SI}$ & SI, FB & Non-contributory invalidity pension \\
\hline RO & $\mathrm{SI}$ & $\mathrm{SI}$ & \\
\hline SK & $\mathrm{SI}$ & $\mathrm{SI}, \mathrm{FB}$ & Social Pension \\
\hline SL & $\mathrm{PI}$ & $\mathrm{PI}, \mathrm{FB}$ & $\begin{array}{l}\text { State pension for handicapped, maintenance } \\
\text { allowances }\end{array}$ \\
\hline SP & $\mathrm{SI}$ & WA, SI, FB & $\begin{array}{l}\text { Cash benefits for the invalids, mobility } \\
\text { allowances, payments of Autonomous } \\
\text { Communities }\end{array}$ \\
\hline SW & $\mathrm{SI}$ & $\mathrm{SI}$ & \\
\hline UK & $\mathrm{SI}$ & $\mathrm{SI}, \mathrm{FB}$ & Income support, disability allowance \\
\hline
\end{tabular}




\section{d) Old Age and Survivors Benefits (Table 4)}

Abbreviations: $\mathrm{PI}=$ Pension Insurance; $\mathrm{SI}=$ Social Insurance; $\mathrm{AP}=$ Additional Pension; $\mathrm{BP}=$ Basic Pension

\begin{tabular}{|c|c|c|c|}
\hline & $\begin{array}{l}\text { Soc. Sec. } \\
\text { (old age) }\end{array}$ & $\begin{array}{l}\text { Soc. Sec. } \\
\text { (death) }\end{array}$ & SNCB \\
\hline AT & $\mathrm{PI}$ & $\mathrm{PI}$ & Compensatory pension allowance \\
\hline $\mathrm{BE}$ & $\mathrm{PI}$ & $\mathrm{PI}$ & Guaranteed income for elderly persons \\
\hline BG & $\mathrm{SI}$ & $\mathrm{SI}$ & Social pension for old age \\
\hline $\mathrm{CZ}$ & $\mathrm{PI}$ & $\mathrm{PI}$ & \\
\hline $\mathrm{CY}$ & $\mathrm{SI}$ & $\mathrm{SI}$ & Social pension \\
\hline DK & $\mathrm{BP}$ & $\mathrm{BP}$ & Accommodation expenses for pensioners \\
\hline ES & $\mathrm{BP}, \mathrm{AP}$ & $\mathrm{BP}, \mathrm{AP}$ & \\
\hline $\mathrm{FI}$ & $\mathrm{BP}, \mathrm{PI}$ & $\mathrm{BP}, \mathrm{PI}$ & Housing allowance \\
\hline FR & $\mathrm{PI}$ & $\mathrm{PI}$ & Old age solidarity Fund, Old Age allowance \\
\hline GE & $\mathrm{PI}$ & $\mathrm{PI}$ & Basic subsistence income for the elderly \\
\hline GR & $\mathrm{PI}$ & $\mathrm{PI}$ & special benefits for the elderly \\
\hline $\mathrm{HU}$ & $\mathrm{PI}, \mathrm{AP}$ & $\mathrm{PI}$ & Non-contributory old age allowance \\
\hline IR & $\mathrm{PI}$ & $\mathrm{PI}$ & $\begin{array}{l}\text { State pension, } \\
\text { Supplementary welfare allowance, } \\
\text { Widow(er)s pension }\end{array}$ \\
\hline IT & $\mathrm{PI}$ & $\mathrm{PI}$ & Social pensions \\
\hline LV & $\mathrm{PI}, \mathrm{AP}$ & $\mathrm{PI}$ & \\
\hline LT & $\mathrm{PI}, \mathrm{AP}$ & $\mathrm{PI}$ & Social assistance pension \\
\hline LU & $\mathrm{PI}$ & $\mathrm{PI}$ & \\
\hline MT & $\mathrm{SI}$ & $\mathrm{SI}$ & Age pension \\
\hline NL & $\mathrm{PI}$ & $\mathrm{PI}$ & \\
\hline $\mathrm{PL}$ & $\mathrm{PI}, \mathrm{AP}$ & $\mathrm{PI}$ & Social pension \\
\hline PT & $\mathrm{SI}$ & $\mathrm{SI}$ & $\begin{array}{l}\text { Non-contributory old age and widowhood } \\
\text { support }\end{array}$ \\
\hline RO & $\mathrm{SI}$ & $\mathrm{SI}$ & \\
\hline SK & $\mathrm{PI}, \mathrm{AP}$ & $\mathrm{PI}$ & Social pension \\
\hline SL & $\mathrm{PI}$ & $\mathrm{PI}$ & State pension for the elderly \\
\hline $\mathrm{SP}$ & $\mathrm{PI}$ & $\mathrm{PI}$ & Cash benefits for the elderly \\
\hline SW & $\mathrm{PI}, \mathrm{BP}, \mathrm{AP}$ & $\mathrm{PI}, \mathrm{BP}, \mathrm{AP}$ & $\begin{array}{l}\text { Financial support for the elderly, housing } \\
\text { allowance }\end{array}$ \\
\hline UK & $\mathrm{BP}, \mathrm{PL}$ & $\mathrm{BP}, \mathrm{PI}$ & State pension \\
\hline
\end{tabular}




\section{e) Unemployment Benefits (Table 5)}

Abbreviations: $\mathrm{MI}=$ Mandatory Insurance; $\mathrm{VI}=$ Voluntary Insurance; $\mathrm{TA}=$ Tax financed allowances

\begin{tabular}{|c|c|c|}
\hline & Soc. Sec. & SNCB \\
\hline AT & $\mathrm{MI}$ & \\
\hline $\mathrm{BE}$ & $\mathrm{Ml}$ & \\
\hline BG & $\mathrm{Ml}$ & \\
\hline $\mathrm{CZ}$ & $\mathrm{Ml}$ & \\
\hline $\mathrm{CY}$ & $\mathrm{Ml}$ & \\
\hline DK & $\mathrm{VI}$ & \\
\hline ES & $\mathrm{Ml}$ & $\begin{array}{ll}\text { State } & \text { unemployment } \\
\text { allowance } & \end{array}$ \\
\hline $\mathrm{FI}$ & $\mathrm{Ml}$ & Labour market support \\
\hline FR & $\mathrm{Ml}$ & \\
\hline GE & $\mathrm{MI}$ & $\begin{array}{l}\text { Basic subsistence costs for } \\
\text { jobseekers }\end{array}$ \\
\hline GR & $\mathrm{Ml}$ & \\
\hline $\mathrm{HU}$ & $\mathrm{Ml}$ & \\
\hline $\mathrm{IR}$ & $\mathrm{Ml}$ & Jobseekers' allowance \\
\hline IT & $\mathrm{Ml}$ & \\
\hline LV & $\mathrm{MI}$ & \\
\hline LT & $\mathrm{Ml}$ & \\
\hline LU & TA & \\
\hline MT & $\mathrm{MI}$ & Supplementary income \\
\hline $\mathrm{NL}$ & $\mathrm{Ml}$ & \\
\hline $\mathrm{PL}$ & $\mathrm{Ml}$ & \\
\hline PT & $\mathrm{Ml}$ & \\
\hline RO & $\mathrm{Ml}$ & \\
\hline SK & $\mathrm{Ml}$ & \\
\hline $\mathrm{SL}$ & $\mathrm{Ml}$ & \\
\hline SP & $\mathrm{Ml}$ & \\
\hline SW & $\mathrm{Ml}$ & \\
\hline UK & $\mathrm{MI}$ & $\begin{array}{l}\text { Income based jobseekers' } \\
\text { allowance }\end{array}$ \\
\hline
\end{tabular}




\section{f) Family benefits (Table 6)}

Abbreviations: I = Insurance; A = Allowance

\begin{tabular}{|l|l|}
\hline & Soc. Sec. \\
\hline AT & I \\
\hline BE & I \\
\hline BG & A \\
\hline CZ & A \\
\hline CY & A \\
\hline DK & A \\
\hline ES & A \\
\hline FI & A \\
\hline FR & I \\
\hline GE & A \\
\hline GR & I \\
\hline HU & A \\
\hline IR & A \\
\hline IT & \\
\hline LV & A \\
\hline LT & A \\
\hline LU & \\
\hline MT & I \\
\hline NL & \\
\hline PL & A \\
\hline PT & I \\
\hline RO & A \\
\hline SK & A \\
\hline SL & A \\
\hline SP & A \\
\hline SW & A \\
\hline UK & A \\
\hline & \\
\hline
\end{tabular}

\section{Evaluation}

The overview of the social benefits of the Member States unveils various arrangements of benefits and a highly diversified benefit structure. This makes it difficult to find a clear and easy access to the topic of residence based social benefits. The overview clearly shows that as to the different risks and institutional settings also differences in the entitlements to 
these benefits can be observed. It is also clear that, with relation to the existence of residence based schemes, no clear division can be made between historically "Bismarck" or "Beveridge" oriented social security systems. They can be detected in every Member State of the European Union, regardless of its historical institutional orientation. Aditionally - and despite the fact that social assistance benefits did not fall within the scope of this overview , it should also be mentioned that the mapping of social benefits revealed that all Member States, with the exception of United Kingdom and Greece, seem to have a general social assistance scheme.

As to the access to health care, the fundamental difference is due to the divergent institutional approaches, namely whether the Member State has chosen a national health service or a health insurance scheme. In Member States with health services the entitlement to health care is based on residence. Member States with health insurances, however, are primarily addressed towards the economically active population and their families. In those systems the non-active persons are not covered by social security, but might be entitled to health care on the basis of a residuary provision related to residence or on the basis of social or medical assistance.

This difference matters for the debate at stake and has a substantial importance. In Member States with health service systems, taking up residence brings about full social protection, whereas in Member States with health insurance schemes, residence does not always coincide with social security integration. Under these circumstances the topic of creating additional burdens by making residents becoming entitled to medical assistance for the economically non-active persons is limited to insurance based health schemes.

It is also worthwhile to mention, that in the whole sector of protection in case of sickness and maternity not only for the benefits in kind, but also for the benefits in cash SNCB do not exist.

For invalidity, old age and survivors benefits it might be possible that the freedom of movement will be used to get access to the SNCB of another Member State. This is likely for beneficiaries of those Member States with inadequate social security benefits to cover these risks, compared with the level of protection that is available under the SNCB regime of another Member State.

Under the legislation of the Member States, the SCNB beneficiaries are conceived as a small group. They represent a minority who, because of unforeseeable and irregular circumstances, suffered from shortcomings in their social protection during their active life. If the access to these benefits is open to all EU citizens, it can be attractive to move to another Member State in order to become entitled to these benefits - even if they are 
intended to give only a minimal protection to the beneficiaries. This attraction can stem from the differences in the economic level of protection of the different Member States. So, also an EU citizen with an adequate - even above average - social security protection in a Member State with a comparatively modest level of social security protection can expect a higher SCNB, when moving to a Member State, with a high level of benefits. The concern to avoid EU migration driven by the motive of getting access to a higher SCNB is to be noticed in relation to persons who are protected under social security systems of a lower economic level.

As the proportion of SCNBs to the unemployed is limited to a small number of Member States, the likelihood that unemployed persons move in order to be entitled to an SCNB in the host Member State is low. As to the characteristics of unemployment benefits, in order to become entitled, it is also not enough to change residence. Additionally, the beneficiary has to be actively looking for paid work and be registered by and available for the employment service of the competent state, when receiving benefits. Finally, for most SCNBs for unemployed persons a substantial period of previous integration into the labour market of a given Member State is required. As to these circumstances, unemployment benefits are not the core of the problem of mobility to be dealt with in this report.

As family benefits are to be qualified as social security benefits and, irrespective of the institutional character of the legislation, insurance or tax based, they are not only restricted to the economically active, but also to the non-active population, the family benefits entitlements are open for migrants. The entitlement does not depend primarily on the children's residence, but on the residence of the parents. From this follows, that the right to benefits can be established under a Member States' legislation, even without the residence of the child, whose protection is the political target of the benefit. This effect can be justified by the peculiarity of family benefits - which are based on the idea of a family unit. 
$28 / 54$ 


\section{Chapter III}

\section{Fact-finding on issues related to the coverage of non-active persons in the Member States}

The following chapter is based on an analysis and synthesis of the replies of the Member States (hereinafter "the responding Member States") to a questionnaire from the Secretariat of the Administrative Commission on the relationship between Regulation 883/2004 and Directive 2004/38. ${ }^{42}$ Exactly 18 of the 31 Member States responded to this questionnaire. ${ }^{43}$ The replies have been processed into a fact-finding analysis of their views on issues related to the transitional coverage of non-active persons in the Member States. More specifically, attention was drawn to the question which persons and which benefits are involved, but we predominantly focus on the topics that were signalled as problematic from the perspective of the Member States, supported by figures or statistics if such were made available.

\section{The definition of non-active persons}

Before commencing an analysis of the reported issues with relation to claims of benefits by "non-active persons" in a host Member State, it is self-evidently very important to investigate whether a common denominator could be derived from the replies of the Member States when it comes to circumscribing this specific category of persons.

When providing a definition of what can be understood under non-active persons, most of the responding Member States in principle seem to designate the same or at least a similar category of persons. Non-active persons are generally described as persons who are not economically active in their host Member State and who have neither coordination rights under Regulation 883/2004 as an employed or self-employed person nor as a family member of an economically active person in that Member State. ${ }^{44}$ They are clearly discerned from

42 CASSTM Note 076/11.

43 Replies were received from Austria, the Czech Republic, Denmark, France, Germany, Ireland, Italy, Latvia, Luxembourg, Malta, the Netherlands, Poland, Portugal, the Slovak Republic, Slovenia, Spain, Sweden and the United Kingdom.

44 Non-active persons are also further categorised in the following categories:

a) Persons who have lost their entitlements in the competent Member State and are living in a noncompetent Member State;

b) Persons who have used the right to free movement and living in a host Member State for up to three months;

c) Pensioners without a sufficient period of insurance that have used the right of free movement and are living in a host Member State;

d) Persons who have used the right of free movement and living in a host Member State for a period of more than three months and have not fulfilled obligations set in the Article $8(1)$ of the Directive 2004/38/EC;

e) Persons who have used the right of free movement and are living in a host Member State for a period of more than three months based on Article 7 (1 (b)) of Directive 2004/38/EC and after a period of time do not have sufficient resources for themselves and/or do not have comprehensive sickness insurance. 
"(currently) economically inactive persons", who have previously been engaged in an economic activity and therefore continue to be covered by the coordination rules of Regulation 883/2004 as employed or self-employed persons. When it comes to naming the more concrete daily life situation and / or legal status that can be attached to this category of persons, reoccurring examples are "single parents", "divorced persons", "disabled persons", "jobseekers", "students", "pensioners" and "homeless persons".

As to their residence status, the concerned non-active persons are mainly viewed as persons who are "newly" ( $<3$ months residence) or "mid-term" ( $\geq 3$ months and $<5$ years residence) residents in the host Member State. As already pointed out, for a legal mid-term residence, economically inactive citizens have to fulfil the conditions with regard to sufficient means and comprehensive sickness insurance of Article 7(1)(b)\&(c) of Directive 2004/38. However, the group of non-active persons described in the replies of the responding Member States appears to be broader than that. Persons who have already been living in the host Member State for several years (even $\geq 5$ years residence), but suddenly end up in a state of indigence due to particular life events, are also envisaged.

This seemingly rather clear view on which persons are involved is, however, just a starting point. It must indeed be added that the Member States' definition of the category of "nonactive persons" becomes slightly confusing when taking into account some rather precarious or totally deviant views of certain Member States on this topic.

First, the status of "non-active person" for nationals of other Member States is sometimes derived from a rather opaque link between an increasing number of newly resident EU nationals and the high unemployment rate in the host Member State. Secondly, this category is also assimilated with the category of "uninsured" persons falling completely outside the scope of Regulation 883/2004 due to a lack of any insurance coverage in any Member State. Lastly, the picture of the category of non-active persons - normally filled in by different sorts of indigent individuals - totally changes as it is also connected to selfsufficient persons with other sources of income in their Member State of origin with a medium/high standard of living who move to another Member State. These different perspectives clearly show that, besides the prima facie consensus about which persons are involved, there is still a considerable amount of uncertainty about the exact contours of the categorisation of non-active persons.

What is certain, is that all persons concerned have never worked in the host Member State and are considered to have no previous attachments to that state, but at a given moment claim certain residence based benefits. The latter belong to the wide variety of residence based benefits in the Member States' welfare schemes and can possibly be classified as 
"social security", including "SNCBs", or "social assistance" within the meaning of Regulation $883 / 2004$.

\section{Benefits involved}

As the reported issues are all related to claims of non-active persons to residence based benefits, the question immediately arises which welfare schemes and which benefits are involved exactly. In other words, where did the responding Member States encounter certain issues "ratione materiae"?

The answer to this question is quite straightforward, as the replies clearly point to the same types of benefits. Of the total of 18 replies from the Member States, 10 replies in some way mention the category of "SNCBs" as laid down in Article 70 of Regulation 883/2004. In 8 replies, "health care" (i.e. sickness benefits as described in Article 3(1)(a) of Regulation 883/2004) was referred to. Three replies also brought up "family benefits" (Article 3(1)(j), Regulation $883 / 2004$ ) in this context.

As to the SNCB concerned, the example can be given of a compensatory pension supplement in order to give pensioners a minimum income so that they can provide for themselves, by making up the difference between the pension and an applicable standard amount. Similarly, supplementary allowances for the elderly or for widow(er)s which provide for a minimum level of resources were referred to. Other typical examples can be found in benefits for disabled persons (or more specific: incapacity / blindness / low mobility) or special benefits specifically created to support jobseekers. Some SNCBs have a potentially wide scope of beneficiaries, whereas for others it is acknowledged that, due to the specific characteristics of the benefit in question, only a very narrow group of beneficiaries can qualify.

With regard to sickness benefits, several responding Member States emphasise that free and equal access to their health care systems can be based purely on "residence", "permanent residence" or "legal residence". Access is granted independently of the economic status of the beneficiary and is often paid by the state and thus free of charge or sometimes related to a contribution by the beneficiary. Next to this residence based entrance to the health care scheme, a subsidiary insurance obligation under the statutory sickness insurance of a host Member State, applying to persons who have no other entitlement to cover in the event of illness, was mentioned. This was reported as the residence status was the decisive factor to determine whether EU (and other non-) nationals are covered. If not, they are obliged to take out private sickness insurance whilst residing in the concerned Member State. 
Only 3 responding Member States referred to the involvement of residence based family benefit schemes, for which beneficiaries can qualify without completing any insurance periods or paying any contributions. It suffices to be resident in the host Member State and to be raising children. One concrete example was related to a family benefit for single parents. It was reported by one responding Member State that these benefits can almost amount to the level of the minimum wage.

\section{Fact-finding on the coverage of non-active persons in the Member States}

Departing from a bird's-eye perspective on the answers to the questionnaire, one must first conclude that, with some exceptions, the reactions from the responding Member States did not contain a sufficient amount of figures, facts or practical examples to get a satisfying overview of the current issues in the Member States with relation to the analysed subject matter, let alone to conclude that there would be an obviously coinciding trend in all the responding Member States. The answers differed too much or did not contain enough background material to come to such an all encompassing ascertainment.

However, this has not prevented the detection of some recurring and therefore horizontal ${ }^{45}$ issues or concerns, which are threefold. First, they are related to very general concerns about social tourism or other undesirable pressure on the solidarity mechanisms that form the foundation of the Member States' welfare schemes. Secondly, several Member States pinpoint an increase of welfare claims from non-active persons with regard to residence based benefits. Lastly, the Member States' concerns relate to more concrete legal questions, namely regarding the entitlement of those non-active persons to SNCBs and sickness benefits under Regulation 883/2004 and how this entitlement correlates to the provisions of Directive 2004/38 and to the - in that regard crucial - concept of "residence".

\subsection{General fear for "social tourism"}

First, it should be mentioned that some of the responding Member States explicitly stated that they had no new issues to report, neither in the context of the coverage of non-active persons nor regarding the relationship between Regulation 883/2004 and Directive 2004/38.

However, several of the responding Member States, even those without specific issues or facts to notify, recognised that a certain uncomfortable vagueness surrounds this topic. Most of these rather general reservations are related to the legal uncertainty with regard to 45 Please not that this does not mean that these issues were mentioned in every reply from the Member
States. It simply means that this issue was an unmistakably recurring one. 
the interference between the aforementioned EU legislative instruments and to a - although not necessarily documented or fact-driven - fear for the possibility of "social tourism".

Objections like "problems of social and health tourism may affect the Member State [...]" or "easy access to welfare services and benefits may lead to an inflow of less skilled immigrants [...]" illustrate these anxieties perfectly. They are inspired by the lack of a "quid pro quo" in the case of non-active persons, receiving residence based benefits which are financed by means of resources to which they have never contributed. Moreover, these fears aggravate in cases where it is obvious that the entitlement to certain benefits constitutes a decisive or perhaps the only motivation to use the right to free movement within the EU.

\subsection{An increase in the number of claims from non-active persons}

Several replies made mention of a recent increase in the number of cases of non-active persons claiming residence based benefits (SNCBs, sickness benefits, family benefits) in the responding Member States, in which they do not perform any economic activity and with which they have no other close connection. Some extracts from the responding Member States' replies can illustrate what is exactly meant by these "cases".

\section{Example 1:}

"The Austrian "Ausgleichszulage", a compensatory pension supplement recognised as an $S N C B^{46}$, was created to guarantee pensioners a minimum income to enable them to provide for themselves. According to the Austrian authorities, there has been a dramatic increase ${ }^{47}$ in the number of cases in which recipients of a small pension from another Member State who did not previously have any close ties with Austria have applied for the right of residence and then obtained the compensatory pension supplement from the first day. It is suspected that in many cases people in reality continue to live in another Member State, but are officially resident in Austria at an address of convenience in order to obtain the compensatory pension supplement."

\footnotetext{
${ }^{46}$ See Annex X to Regulation 883/2004 and Case C-160/02, Skalka [2004] ECR I-5613.

${ }^{47}$ See infra Table 7.
} 


\section{Example 2:}

"The United Kingdom provides several examples with regard to lone parents claiming UK benefits:

- [A lone parent] moved to UK from another Member State. 3 children under school age. Has never worked, is not seeking work and claims UK benefits as a lone parent.

- Young woman aged 21 with 3 month old baby. Came to UK with parents 6 years ago, has never worked and always lived with parents until they threw her out. Claiming UK benefits.

- Young disabled woman came to UK at age 12 with parents. Is now 21. Has child and has never worked. Claiming UK benefits.

- Woman (lone parent) moved to UK from another Member State with children. Never worked. Claiming UK benefits."

\section{Example 3:}

"While the Czech Republic does not experience particular flow of inactive migrants, the institutions have noticed several cases where certain families moved in the Czech Republic to basically live off social benefits.

Example: An entirely inactive family moves their residence to the Czech Republic - an unemployed father with a mother raising a dependent child (under 4 years). The father registers with the employment services and receives vocational training. In such circumstances, the whole family would get a healthcare coverage for free (contributions with respect to all three persons would be paid by the State) and they could receive - basically on their arrival - both Parental allowance and Re-qualification benefit without having ever worked in the Czech Republic and without contributing to the Czech scheme."

\section{Example 4:}

"As regards health care, we have noticed an increase of claims made by non-active persons and their family members (children), to be entitled to healthcare under the National Health Service (NHS) and, therefore, to get NHS user's card. [...] In fact, they are mostly persons with other sources of income in their countries of origin with a medium/high standard of living who decide to come to live in Portugal and invoke the residence in this country under the Regulation 883/2004 in order to have access to the NHS [...]." 
Considering these examples, it becomes entirely clear that some of the responding Member States find the reported augmentation of residence based access to their welfare system problematic when it concerns non-active persons moving to the Member State. It must however already be added that only a small minority of the responding Member States backed up such expressed concerns with official figures and statistics (see Tables 7-8).

An interesting aspect of the evaluation of this reported increase is the possible influence of the personal scope of Regulation 883/2004 in this area. Considering that the social security coordination system has left behind any reference to economic activity (as opposed to the former Regulation 1408/71), some Member States assume a link between the broadened personal scope of the regulation and the increase of claims from non-active persons. A small minority of the responding Member States even explicitly argues that the increased number of claims should be attributed to non-active persons who were previously not included in the scope of Regulation 1408/71. ${ }^{48}$ Most responding Member States, however, do not suggest this interdependence and $1 / 3$ of this group even explicitly excludes a causal link between the broad personal scope of the modernised coordination system and the increase of claims from non-active persons. They contend that the very wide interpretation of the terms "employed person" and "self-employed person" under the personal scope of Regulation $1408 / 71$ could already produce similar issues and that the new regulation has not caused a significant change for the access of non-active persons to residence based benefits that fall under its material scope. The authors of this report fully agree with this view.

As to the widened personal scope of social security coordination, none of the responding Member States could give an estimate of the number and category of persons who are now covered by Regulation $883 / 2004$, but did not fall within the personal scope of Regulation $1408 / 71$. Most responding Member States reported that this information is not available, some of them emphasising that this is irrelevant, considering that the issue should not be framed as one that is linked to the entry into force of Regulation 883/2004.

\subsection{The ambiguous relationship between Regulation 883/2004 and Directive 2004/38}

Considerable confusion is noticeably caused by the unclear relationship between Regulation $883 / 2004$ and Directive $2004 / 38$. It can be derived from several replies that the responding

\footnotetext{
48 In this context, it was remarked by a responding Member State that the change in the personal scope of the coordination system was not accompanied by an assessment of which groups were targeted or of the impact on the budget of the Member States. A reference was made to Article 11, 3, e, Regulation 883/2004, pointing out the fact that this article does not make a distinction between beneficiaries of long-term benefits (invalidity, old-age or survivors' pensions, pensions in respect of accidents at work or occupational diseases or sickness benefits in cash covering treatment for an unlimited period) and "other non-active persons". The latter are also referred to as "pure non-active persons".
} 
Member States are uncertain about the possible interplay between these two instruments. More particularly, two dominant questions come to the fore.

On the one hand, the Member States' legislation and administrative practice mentioned in the replies show that there are severe doubts about whether coordination rights with regard to SNCBs and sickness benefits can be invoked to fulfil the residence conditions laid down in Article $7(1)(b) \&(c)$ of Directive 2004/38. On the other hand, it is still unsure whether these benefits could be qualified as "social assistance" within the meaning of Directive 2004/38. Such qualification would not only open the possibility for the Member States to make a connection between an appeal to these coordination rights and the assessment of the legality of the residence of the non-active person, but would also enable them to legitimately derogate from the equal treatment principle, within the limits of Article 24(2) of Directive 2004/38.

This state of uncertainty immediately catches the eye when a comparison is made between the different ways the responding Member States tackle the relationship between the coordination rights according to Regulation 883/2004 and the residence and corresponding equal treatment rights and exceptions in Directive 2004/38. In general, several responding Member States explicitly favour the establishment of legal residence according to Directive 2004/38, before non-active persons would be able to invoke their social security coordination rights.

Different Member States seem to agree that the entitlement to an SNCB in a host Member State should not enable non-active persons to fulfil the sufficient resources requirement of Article $7(1)(b) \&(c)$ of Directive 2004/38. However, it appears from the replies that not all Member States bring this conviction into practice. In this sense, it was reported by a Member State that, as a matter of principle, it considers the derivation of a residence right for non-active persons from entitlement to an SNCB in the host Member State to be incorrect. However, this does not seem to prevent this Member State to consistently apply the factual residence concept of Regulation 883/2004, using the criteria laid down in Article 11 Regulation 987/2009, to assess the entitlement to an SNCB. ${ }^{49}$ "Legal residence" or "equal treatment derogations" following from the provisions Directive 2004/38 are not involved in this assessment.

This is, however, obviously not the case in every responding Member State. In one Member State, the national legislation has recently been adapted in order to change the qualification of a particular SNCB to "social assistance within the meaning of Directive 2004/38". This change was inspired by suspicions of abuse and social tourism. Another example also

49 Which is to our opinion still the correct approach to handling such claims, given the current state of EU law. See Chapter IV, point 1 of this report on the current state of EU law. 
concerns a Member State's legislation with relation to an SNCB, in which entitlement to this benefit is excluded during the first three months of stay, if the foreign national is not a worker or a self-employed person or has not kept such an economic status. This means that an "Article 24(2) Directive 2004/38-like exception" is already foreseen in the national legislation for the SNCB concerned. A final example relates to the administrative practice of a Member State with regard to non-active persons who have lost all entitlements associated with their previous insured status or residence in another Member State. Before examining any other condition for the award of any benefits that are granted subject to "legal residence", including SNCB and sickness benefits, the national institutions first check the legality of the residence, i.e. whether the non-active person has sufficient means and a comprehensive sickness insurance.

These examples make it very clear that in some Member States, the provisions of Directive 2004/38 have already found their way into the coordination of benefits falling under the material scope of Regulation 883/2004. In some countries it has also been examined how qualifying periods for entitlement to residence based benefits and services can be used to reduce "unintended use".

It goes without saying that this inconsistent application of EU law in different Member States is the consequence of the doubts and the differing views that still exist concerning the interference between the relevant legislation in the field of the free movement of persons. For that matter, the perception of the concept of residence in EU law as an ambiguous and unclear notion plays a very important role. In the next chapter, particular focus will be dedicated to the current state of EU law and the possible ways forward in this area.

\section{Figures and statistics}

In order to gather all relevant information with regard to possible issues concerning nonactive persons between the Member States, the latter were asked to supply any statistical information on the number of cases related to possible issues with non-active persons, as well as any other relevant statistical evidence. However, almost no responding Member States could provide such information.

Whereas one Member State supported the regular occurrence of claims from non-active persons by a reference to a "consultation of the offices" without further specifications, the vast majority of the responding Member States declared that no such data were available in their systems. Three Member States (Austria, France and the United Kingdom) did provide some statistical information to back up the issues mentioned in their replies. 
In the reply from Austria, statistics were provided concerning the number of recipients of the aforementioned compensatory pension supplement (“Ausgleichszulage"), an SNCB. Table 7 gives an overview of the number of recipients of this benefit between December 2009 and March 2011 and indeed shows an increase. The reply from France also contained some statistical material, namely with regard to the number of recipients of a solidarity allowance for the elderly ("Allocation de Solidarité aux Personnes Agées"), also an SNCB, and of state provided medical assistance. For both benefits, the number of beneficiaries who are EEA nationals has also increased in recent years. The same goes for the number of EEA nationals applying for SNCBs in the UK (Table 8). The number of beneficiaries of UK SNCBS has not augmented due to the relatively higher number of refused applications.

Next to the fact that these figures show an increase of the number of claimants and/or beneficiaries of residence based benefits, no further background information or explanation is provided in either one of the examples. 


\section{a) Austria: “Ausgleichszulage” (SNCB) (Table 7)}

Development EWR - “Ausgleichszulage” recipients: March 2011 compared with December 2009

\begin{tabular}{|c|c|c|c|c|c|c|c|}
\hline $\begin{array}{l}\text { Foreign benefit } \\
\text { from }\end{array}$ & $\begin{array}{r}\text { Dec } \\
2009\end{array}$ & $\begin{array}{l}\text { March } \\
2010\end{array}$ & $\begin{array}{l}\text { June } \\
2010\end{array}$ & $\begin{array}{c}\text { Sep } \\
2010\end{array}$ & $\begin{array}{l}\text { Dec } \\
2010\end{array}$ & $\begin{array}{c}\text { March } \\
2011\end{array}$ & $\begin{array}{c}\text { Change } \\
\text { since Dec } \\
2009\end{array}$ \\
\hline $\mathrm{BE}$ & 1 & 1 & 1 & 1 & 1 & 1 & $0 \%$ \\
\hline BG & 17 & 21 & 29 & 37 & 53 & 61 & $259 \%$ \\
\hline \multicolumn{8}{|l|}{ DK } \\
\hline GE & 366 & 369 & 381 & 386 & 391 & 394 & $8 \%$ \\
\hline $\mathrm{EE}$ & & & & 1 & 1 & 1 & \\
\hline \multicolumn{8}{|l|}{$\mathrm{FI}$} \\
\hline FR & 6 & 8 & 8 & 7 & 7 & 8 & $33 \%$ \\
\hline $\mathrm{EL}$ & 1 & 1 & 1 & 1 & 1 & 1 & $0 \%$ \\
\hline UK & 25 & 26 & 25 & 28 & 29 & 29 & $16 \%$ \\
\hline \multicolumn{8}{|l|}{ IE } \\
\hline \multicolumn{8}{|l|}{ IC } \\
\hline IT & 18 & 19 & 17 & 16 & 17 & 17 & $-6 \%$ \\
\hline LV & 2 & 2 & 2 & 2 & 2 & 2 & $0 \%$ \\
\hline LI & 1 & 2 & 4 & 5 & 5 & 5 & $400 \%$ \\
\hline \multicolumn{8}{|l|}{ LT } \\
\hline \multicolumn{8}{|l|}{ LU } \\
\hline \multicolumn{8}{|l|}{ MT } \\
\hline $\mathrm{NL}$ & 6 & 6 & 6 & 6 & 6 & 6 & $0 \%$ \\
\hline \multicolumn{8}{|l|}{ NO } \\
\hline $\mathrm{PL}$ & 36 & 39 & 41 & 46 & 50 & 53 & $47 \%$ \\
\hline PT & 1 & 1 & 1 & & & & \\
\hline RO & 31 & 47 & 68 & 90 & 100 & 112 & $261 \%$ \\
\hline SE & 4 & 6 & 6 & 7 & 8 & 9 & $125 \%$ \\
\hline $\mathrm{CH}$ & 15 & 17 & 22 & 22 & 22 & 22 & $47 \%$ \\
\hline SK & 4 & 5 & 5 & 10 & 10 & 12 & $200 \%$ \\
\hline SI & 9 & 9 & 11 & 11 & 11 & 11 & $22 \%$ \\
\hline ES & & & & & 1 & 1 & \\
\hline$C Z$ & 2 & 2 & 3 & 3 & 3 & 3 & $50 \%$ \\
\hline $\mathrm{HU}$ & 10 & 9 & 11 & 15 & 16 & 16 & $60 \%$ \\
\hline $\mathrm{CY}$ & & & & & & & \\
\hline Total result & 555 & 590 & 642 & 694 & 734 & 764 & $38 \%$ \\
\hline
\end{tabular}




\section{b) France: “Allocation de Solidarité aux Personnes Agées” (SNCB) and health care}

\section{"Minimum old-age benefit":}

The solidarity allowance for the elderly (ASPA) is currently granted to 583000 persons, or 4 $\%$ of the population over 60 . We do not have any statistical breakdown by nationality as regards the current and potential future award by the French pension authorities of the "minimum old-age benefit" to European nationals in receipt of benefits on the grounds of old age.

Concerning applications for benefits from persons not receiving benefits on the grounds of old age, the most recent data suggest that, as at 31/12/2010, $35.6 \%$ of the 70919 recipients were non-nationals, of whom 3.5\% were European nationals and $32.1 \%$ were non-EEA foreign nationals. In numerical terms, benefits were granted to 2255 foreign nationals in 2010, of whom 234 were EEA nationals. Since 2008, the number of beneficiaries who are EEA nationals has shown an increase, rising from 194 in 2008 to 449 - representing $7 \%$ of total benefits - in 2009.

\section{Health care:}

The French medical insurance funds do not identify the nationality of persons in their information system when assigning rights to the general medical insurance scheme under Regulation 883/2004, to universal health cover (CMU), or to state provided medical assistance (AME) for foreign nationals who have no health care or who are not legal residents and whose resources are below $€ 7611$ /year (or €634/month) for a single person.

Of the 227000 recipients of state provided medical assistance in June 2010, a recent study showed that the proportion of EEA nationals entering the scheme in the second quarter of 2010 was $8 \%$, an increase of $14 \%$ relative to the first quarter of $2010.37 \%$ had been in France for less than one year, $36 \%$ between one and two years and $27 \%$ for more than two years. 
c) United Kingdom: SNCBs (Table 8)

Estimates based on clerically gathered information of people who have applied for cash SNCBs:

\begin{tabular}{|l|l|l|}
\hline & $2008-2009^{50}$ & $2009-2101$ \\
\hline $\begin{array}{l}\text { Number of EEA citizens } \\
\text { applying for cash SNCBs }\end{array}$ & 34116 & 42810 \\
\hline $\begin{array}{l}\text { Number of applications } \\
\text { refused }\end{array}$ & 22270 & 27621 \\
\hline $\begin{array}{l}\text { \% of applications } \\
\text { unsuccessful }\end{array}$ & $65 \%$ & $64 \%$ \\
\hline
\end{tabular}

${ }^{50}$ Information of annual figures from April-March. 


\section{Chapter IV}

\section{Evaluation and possible future perspectives}

It is crystal clear that the responses from the Member States have not provided a complete image of the concerns that were expressed by some Member States with regard to the access of non-active persons to residence based benefits in the Member States. Uncertainty still remains about which persons and which benefits are exactly involved as well as about the size and the precise impact of certain allegedly problematic issues. We have been able to find some common ground on what could be regarded as "non-active persons" and it is certain that concerns are mainly directed towards SNCBs and sickness benefits. However, the general lack of case studies, figures and statistics impedes a clear insight.

Be that as it may, the vagueness impeding the detection of trends or common factual problems does not prevent a legal assessment of the currently paramount issue with regard to the access of non-active persons to social benefits in the Member States, namely the relationship between the European system for coordination of social security on the one hand and the EU legislation with regard to movement and residence of Union citizens and their family members on the other hand. In this final chapter, we will try to clarify it by analysing the current state of EU law in this context, but also by connecting this subject to the relevant developments in the ECJ case law. To conclude, some paths for future developments are explored.

\section{The current state of EU Law}

The relationship between Regulation $883 / 2004$ and Directive $2004 / 38$ is quite clear from a certain perspective, as none of both instruments refers to the other, from which one could derive that they should be assessed separately and that they certainly do not explicitly influence each other. However, important questions remain on possible implicit interference between both instruments. Can the coordination rights under Regulation 883/2004 be used to fulfil the requirements of Directive 2004/38 and could the restrictions in this residence directive be applied to benefits which are coordinated under Regulation 883/2004, such as SNCBs and sickness benefits? Or, put differently, can the right to SNCBs and sickness benefits in a host Member State be made subject to the possession of a residence right in accordance with Directive 2004/38?

Departing from the residence conditions laid down in Article $7(1)(b) \&(c)$ of Directive 2004/38, it must first be observed that the ECJ has repeatedly held that as long as the concerned person has sufficient resources, the origin of these resources is not relevant for the fulfilment of the condition, as it is not necessary for the attainment of the objective 
pursued, namely the protection of the public finances of the Member States. ${ }^{51}$ This means that entitlement to a social (security) benefit or to health care coverage on the basis of EU law is certainly able to provide a basis for a residence right in the host Member State in accordance with Directive 2004/38. ${ }^{52}$ However, whereas this is undoubtedly the case for the entitlement to exported benefits or health care coverage at the expense of another Member State than the host Member State, doubts arise when these entitlements are at the expense of the latter. In that case, the beneficiary weighs on the public finances of this State.

The pivotal question in this regard is whether the beneficiary of such benefits weighs on the "social assistance system" of this Member State, as the provisions of Directive 2004/38 try to prevent. Indeed, restrictions could be placed on the entitlement to SNCBs and sickness benefits in a host Member State, were such benefits are to be qualified as "social assistance" within the meaning of Directive 2004/38. An appeal to these entitlements could then possibly be regarded as an unreasonable burden on the social assistance system of the host Member State, which could - although not automatically ${ }^{53}$ - lead to the end of the residence right of the person concerned. Moreover, the equal treatment derogation with regard to social assistance in Article 24(2) of Directive 2004/38 could be applied to SNCBs and sickness benefits.

However, Directive 2004/38 does not contain a definition of social assistance. Consequently, it is not certain whether this concept can be assimilated with the social assistance concept of Article 3(5) of Regulation 883/2004. This would immediately exclude SNCBs and sickness benefits from the social assistance notion in Directive 2004/38. The reference to "social assistance system" in the directive could indicate that it covers more than the narrowly defined notion of social assistance under Regulation 883/2004, but that is just an assumption as any other and does not answer the question whether SNCBs or sickness benefits could be regarded as such. The only certainty is that the precise extent of this notion remains unclear without further guidance from the European legislator or from the $E C J$, which until now has only taken away a small part of the vagueness by excluding specific benefits.

In Vatsouras and Koupatantze, the ECJ gave a narrow interpretation of the concept of "social assistance" within the meaning of Article 24(2) of Directive 2004/38. The ECJ decided that benefits of a financial nature which, independent of their status under national law, are intended to facilitate access to the labour market cannot be regarded as constituting "social

51 Case C-200/02 Zhu and Chen [2004] I-9925, para 33 and Case C-408/03 Commission v. Belgium [2006] I2647, para 41.

52 Such entitlement was even explicitly mentioned in the former Directive 90/365.

53 Article 14(3) Directive 2004/38 provides that an expulsion measure shall not be the automatic consequence of a Union citizen or his or her family member's recourse to the social assistance system of the host Member State, as already mentioned. 
assistance" within the meaning of this provision. ${ }^{54}$ The ECJ referred in this respect to the interpretation in accordance with Article 45 TFEU on the free movement for workers, which also applies to jobseekers.

In spite of the ECJ's narrow interpretation of the concept of "social assistance" in Directive $2004 / 38$, it nevertheless does not seem to be impossible that, from the perspective of the residence directive, ${ }^{55}$ a number of the benefits listed in Annex X of Regulation 883/2004 could be classified as social assistance within the meaning of Directive 2004/38. In this context, income support for retired or disabled persons comes to mind, in particular when such persons cannot rely on Article 45 TFEU. Yet, such benefits continue to fall simultaneously within the category of social security and social assistance.

However, an analysis of both instruments seems to indicate that they cannot affect each other and that entitlement to SNCBs as well as to sickness benefits under Regulation $883 / 2004$ cannot be made subject to the conditions for legal residence under Directive $2004 / 38$. This must be the conclusion when one legally analyses the totally separated and differing residence notions (factual residence in Regulation 883/2004 versus legal residence in Directive 2004/38) in these instruments, especially in the light of the respective aims of both pieces of secondary legislation.

The provisions of Regulation $883 / 2004$ granting access to non-contributory minimum benefits or health care coverage in the State of residence as well as the definition of the concept of "residence" in Article 11 of Regulation 987/2009, in no manner refer to the residence requirement as being a requirement for which the legal status of the residence would be relevant. ${ }^{56}$ Neither do they make their application subject to the fulfilment of the criteria for obtaining a residence right under Directive 2004/38 or its predecessors.

Which concrete impact does Directive 2004/38 have on the coordination system then? There are only two answers possible. One can say, coordination is to be interpreted on the basis of residence law or both spheres of law are independent from one another. Under the first approach, restrictions in the residence directive are to be translated into coordination. Under the second approach, both systems are conceived as mutually independent from one another and the inquiry is restricted to analyse the consequences of the duplicity of noninterfering rules to the same subject matter.

54 Cases C-22/08 and C-23/08, Vatsouras and Koupatantze [2009] ECR I-4585, para 45.

55 It should be repeated here that, from the perspective of the coordination regulation, these benefits are definitely not considered as social assistance but as special benefits which also fall under the scope of the system for the coordination of social security.

56 The ECJ also never referred to the former or current residence directives when interpreting the residence notion of the former Regulation 1408/71. 
It seems to follow from the absence of any reference in Regulation 883/2004 to the person's status under Directive 2004/38, that entitlement to the SNCBs listed in Annex X of Regulation $883 / 2004$ is only subject to the condition of a person having his habitual centre of interest in a Member State and does not depend on the legal nature of this residence under Directive 2004/38 (provided of course this person fulfils the other relevant criteria under the national legislation such as an income threshold). Relying on Regulation 883/2004, he can be entitled to an SNCB from the first day of "factual residence", which can provide him with sufficient resources as envisaged by Directive 2004/38.

Interpreting these provisions differently and making entitlement to these benefits subject to the fulfilment of the conditions to obtain a residence right under Directive 2004/38, including having sufficient means of subsistence, would make this special coordination system meaningless. Indeed, if an economically inactive person would be denied entitlement to an SNCB listed in Annex X to Regulation 883/2004 because of Article 24(2) of Directive $2004 / 38$ or even if he would jeopardise his right of residence by claiming a benefit under Regulation 883/2004, this would deprive the provisions of Regulation 883/2004 of their effectiveness. It would also undermine the balance agreed by the EU legislature between the limitations on the export of these benefits in the event of migration and the obligation for the new Member State of residence to grant the benefits listed in Annex X. This balance was the price the Member States were prepared to pay for the right not to export these benefits and to stop their payment to persons no longer residing on their territory. Besides, each of the benefits in Annex $X$ was only listed therein after the explicit request of the Member States concerned.

Any other conclusion would deny the very essence of social security coordination, more specifically preventing migrant persons from falling between two stools. It would constitute a clear obstacle to the exercise of the right to free movement, recognised as a fundamental right under the treaties and the Charter, the limitations of which must be interpreted narrowly.

The same conclusion can be drawn with regard to the entitlement to health care coverage in the host Member State, on the basis of the equal treatment provisions of Article 4 Regulation 883/2004. In a situation where the Regulation designates the Member State of residence as the competent Member State, this Article guarantees equal access to the residence based sickness benefits of a host Member State as soon as the person establishes his habitual centre of interest there. Moreover, it even seems fully supported by the text of Directive 2004/38 that the entitlement to sickness benefits under Regulation 883/2004 cannot be regarded as a burden on the "social assistance system" of a host Member State. Article 7(1)(b)\&(c) of Directive 2004/38 does not contain any reference to "not becoming a burden on the social assistance system of the host Member State" with regard to the 
comprehensive sickness insurance requirement, as is the case for the sufficient resources requirement. This indicates that the appeal to sickness benefits in the host Member State can in no way be regarded as an appeal to the social assistance system of that Member State.

Consequently, under the current state of EU law, an economically inactive migrant person can be entitled to a special non-contributory benefit listed in Annex $\mathrm{X}$ of Regulation $883 / 2004$ of the State of (habitual) residence and to the health care coverage in that State, despite the provisions of Directive 2004/38. Such a conclusion seems to be endorsed by the recent case law of the ECJ that Union citizens cannot derive less rights from Directive 2004/38 than from other sources of secondary EU law. ${ }^{57}$

Yet, other minimum subsistence benefits not covered by Regulation 883/2004 and its special coordination regime for the SNCBs listed in its Annex X, remain subject to other provisions of EU law, including those of Directive 2004/38 limiting the access to social assistance benefits in the host Member State.

From a strictly legal point of view, there are no elements in the current state of EU law to establish that any provision of Directive 2004/38 would have any influence on the normal application of Regulation 883/2004. This application remains the same, in particular as to the interdependence between the right to SNCBs and the sufficient resources requirement and between the right to residence based sickness benefits in the host Member State and the requirement of having comprehensive health insurance coverage.

\section{The Treaty-based right to equal treatment for all Union citizens and its limitations}

As a starting point, it should be reminded that Article 21 TFEU guarantees citizens of the Union the right to move and reside freely within the EU, subject to the conditions and restrictions laid down by Union law. In the landmark case Martinez Sala ${ }^{58}$, the ECJ attached to this freedom a right to equal treatment for lawfully resident Union citizens in all situations which fall under the material scope of EU law. Such situations include those involving the mere exercise of the right to move and reside freely in another Member State ${ }^{59}$. A substantial part of the "post Martinez Sala"-case law with regard to equal treatment rights for Union citizens concerned the access of economically inactive persons to residence based

\footnotetext{
57 See references in footnote 11 above.

${ }^{58}$ Case C-85/96, Martinez Sala [1998] ECR I-2691

${ }^{59}$ Case C-184/99, Grzelczyk [2001] ECR I-6193, para 33 and Case C-158/07 Förster [2008] ECR I-8507, para 37.
} 
social benefits in a host Member State. The Court thus created a Treaty-based equal treatment right to residence based social benefits for Union citizens in a cross-border situation, regardless of possible entitlements under secondary EU law.

Next to the legal view on the current relationship between Regulation 883/2004 and Directive 2004/38, one should however take into account the expressed concerns of the Member States with regard to the access of non-active persons to residence based benefits. When these persons are not economically active in the host Member State and do not have any other previous attachments to that State, these concerns generally come down to the aim of the Member States to avoid an unreasonable burden on their public finances and to assure that the persons concerned can demonstrate a certain degree of integration, with a view to the protection of the financial balance of their social security system. Some Member States explicitly favour an approach according to which non-active persons would need to demonstrate a certain stabile affiliation to the concerned Member State before they are granted residence based benefits via the coordination system.

It must be observed that the ECJ has declared, in the aforementioned series of judgments regarding access to non-contributory social benefits, that such aims are legitimate and are capable of justifying restrictions on the rights of freedom of movement and residence under Article 21 TFEU. ${ }^{60}$ Whereas this case law predominantly concerned benefits falling outside the scope of Regulation 883/2004 (such as genuine social assistance benefits ${ }^{61}$, benefits for war victims ${ }^{62}$ and study loans or grants ${ }^{63}$ ), also national legislation with regard to benefits coordinated by this regulation was already affected by the genuine link requirement. ${ }^{64}$

The ECJ also reiterated at different occasions that the measures restricting the free movement of Union citizens, in order to guarantee such a legitimate objective, must certainly not go further than is necessary to achieve that aim. ${ }^{65}$ Moreover, the measures to ensure a genuine link between a claimant of a benefit and the competent Member State

60 This aim was first recognised as a legitimate objective in the D'Hoop case. Case C-224/98 D'Hoop ECR [2002] I-6191, para 38.

61 Case C-184/99, Grzelczyk [2001] ECR I-6193 and Case C-456/02, Trojani [2004] ECR I-7573.

62 Case C-192/05 Tas-Hagen and Tas [2006] ECR I-10451; Case C-499/06 Nerkowska [2008] ECR I-3993 and Case C-221/07 Zablocka-Weyhermüller [2008] ECR I-9029.

63 Case C-209/03, Bidar [2005] ECR I-2119 and Case C-158/07 Förster [2008] ECR I-8507.

64 Case C-138/02, Collins [2004] ECR I-2703; Case C-212/05, Hartmann [2007] ECR I-6303; Case C-213/05, Geven [2007] ECR I-6347; Case C-287/05, Hendrix [2007] ECR I-6909, and very recently Case C-503/09, Stewart, nyr. In most of these cases, the relevant coordination rules could not be applied in the given circumstances. The Hendrix case was a notorious exception, as the ECJ used the genuine link requirement to possibly overrule a residence requirement in the national legislation concerning an SNCB and thus to indirectly assess the non-export rule with regard to SNCBs in Regulation 1408/71.

65 Case C-138/02, Collins [2004] ECR I-2703, para 72; Case C-406/04 De Cuyper [2006] ECR I-6947, para 40; Case C-192/05 Tas-Hagen and Tas [2006] ECR I-10451, para 33; C-221/07 Zablocka-Weyhermüller [2008] ECR I-9029, para 37; Case C-544/07, Rüffler [2009] ECR I-3389, para 74 and Case C-503/09, Stewart, nyr, para 87. 
should consequently be assessed in the light of the proportionality principle, as a fundamental principle of EU law. In essence, this requires that a person should be enabled to demonstrate his or her degree of integration via a variety of relevant connecting factors or criteria, taking into account all individual circumstances of the case. A dominant connecting factor or criterion for the establishment of the genuine link should thus be avoided.

In several of these "Union citizenship judgments", a residence duration condition - i.e. a requirement to have been resident in the host Member State for a certain period of time was accepted by the ECJ as an appropriate criterion to demonstrate a certain degree of integration in a host Member State. ${ }^{66}$ However, taking into account the intensive proportionality requirement in this area, a certain period of previous residence should in principle not be used as a monolithical criterion. ${ }^{67}$ The ECJ very recently stressed this point of view" 68 "Indeed, by requiring specific periods of past presence in the competent Member State, the condition of past presence unduly favours an element which is not necessarily representative of the real and effective degree of connection between the claimant [to shortterm incapacity benefit in youth] and that Member State, to the exclusion of all other representative elements. It therefore goes beyond what is necessary to attain the objective pursued". ${ }^{69}$ This is very logical, as a residence duration condition alone can never reveal the real bond a person has built up with a host Member State. ${ }^{70}$

66 Case C-138/02, Collins [2004] ECR I-2703, para 72; Case C-209/03, Bidar [2005] ECR I-2119, para 61 and Case C-158/07 Förster [2008] ECR I-8507, para 52.

67 See also K. LENAERTS en T. HEREMANS, "Contours of a European Social Union in the Case-Law of the European Court of Justice", EuConst. 2006, 2, (101) 114. In the Förster case, which concerned access to study loans and grants in a host Member State, the ECJ has deviated from this intensive proportionality requirement in an explicit choice for legal certainty and transparency. Case C-158/07 Förster [2008] ECR I8507, para 57.

68 In this judgment, the ECJ was very clear with relation to the restricting nature of conditions relating to past presence in general: "Legislation, [...], which makes acquisition of the right to short-term incapacity benefit in youth subject to a condition of past presence is likely, by its very nature, to deter claimants [...] from exercising their right to freedom of movement and residence by leaving the Member State of which they are nationals to take up residence in another Member State. Indeed, while claimants who have not made use of the opportunities offered by the Treaty in relation to freedom of movement and residence can easily satisfy the abovementioned condition, that is not the case for claimants who have taken advantage of them. It is actually very probable that the latter, because they have take up residence in another Member State, do not satisfy that condition“. Case C-503/09, Stewart, nyr, para 85. See also the Opinion of Advocate General Cruz Villalón with regard to the „suspicion“ towards conditions relating to residence under EU law. Opinion of Advocate General Cruz Villalón in Case C-503/09, Stewart, nyr, para 36.

69 Case C-503/09, Stewart, nyr, para 95 . See, by analogy, also the first case related to the genuine link requirement, Case C-224/98 D'Hoop ECR [2002] I-6191, para 39.

70 This works in both ways. An exclusive residence duration condition can be too strict, as a person can possibly demonstrate a genuine link with the Member State if other circumstances of the case are taken into account. It might, however, also be too flexible, as some persons might easily sit out the required duration of residence without having ever really built up the required genuine link with that Member State. A residence condition may thus be very practical to administer, on its own it is certainly not the golden solution in the search for a genuine link between a claimant of a benefit and a competent Member State. $F$. VAN OVERMEIREN, Additional Welfare Rights through Citizenship of the Union, Doctoral Thesis 2011, nyp, 634-635. 
The main question is whether this trend in the case law is of any particular influence on the access to SNCBs. Upon a closer look at the SNCB regime, this seems not to be the case and one could even argue that the SNCB regime - as it stands now - already ensures the existence of a genuine link between the claimant of such a benefit and his Member State of residence.

With regard to SNCBs, it was already analysed above ${ }^{71}$ that the European legislator and the ECJ both accepted the (factual) habitual residence condition of Regulation 883/2004 as creating a sufficiently genuine link between the claimant and the host Member State for the entitlement to such mixed benefits. This was a crucial element of the balance achieved after the neutralisation of the export principle for these specific benefits.

In the light of the aforementioned case law, it should however be emphasised that this notion in Regulation 883/2004 also seems to fit perfectly into the main tendency of the ECJ case law concerning the requirement of a certain degree of integration. The variety of elements that has to be taken into account to establish whether a person has his habitual centre of interest in a Member State indeed appears to be in harmony with the case law concerning the "genuine link". This variety of factors was introduced by the ECJ's interpretation of the residence concept ${ }^{72}$ in Regulation 1408/71 and is now in a further elaborated form codified in Article 11 of Regulation 987/2009, according to which, in case of a difference of views ${ }^{73}$ between the institutions of two or more Member State, an overall assessment of all available information relating to the relevant facts should be performed in order to determine the centre of interest of a person. The duration and continuity of presence on the territory is one element in this assessment, but cannot be more decisive than other relevant elements. ${ }^{74}$ This evaluation based on all the relevant individual circumstances of the case aligns with the way the ECJ has interpreted the establishment of a certain degree of integration between a claimant of certain social benefits and the granting Member State. The same holds true for the equal access to residence based sickness benefits in a competent Member State of residence.

The case law of the ECJ has proven that EU law is sensitive to the Member States' desire of the establishment of a genuine link between a person claiming residence based noncontributory benefits and the Member State granting the benefit. The residence concept of Regulation $883 / 2004$ also seems to meet these aspirations, both formally and substantially.

71 Cf. Chapter I, point 3.2.

72 Case 76/76 Di Paolo [1977] ECR 315, para 17-20, and Case C-102/91 Knoch [1992] ECR I-4341, para 21-23 and Case 90/97 Swaddling [1999] ECR I-1075, para 29.

73 Although this article serves in the first place as a reconciliation tool in case of disagreement between social security institutions, it of course also provides good guidance for the Member States on how the residence notion of Regulation 883/2004 must in principle be interpreted.

74 As explicitly acknowledged by the ECJ in the Swaddling case. Case 90/97 Swaddling [1999] ECR I-1075, para 30. 
The residence notion of Regulation 883/2004 was not only formally accepted as a solid basis for entitlement to SNCBs and residence based sickness benefits in a competent Member State of residence, but also seems to be in line with the substantial requirements developed for the establishment of a genuine link with the host Member State for access to non-contributory benefits. Consequently, no further requirements to ensure a "genuine link" can be attached to the entitlement to these benefits.

\section{Exploring the possible ways forward}

It must be noted that the current state of EU law obviously causes confusion with regard to the precise relationship between Regulation 883/2004 and Directive 2004/38, particularly as to the access of non-active persons to residence based benefits in a host Member State. This situation of uncertainty will probably last until the ECJ gets the opportunity to provide further clarification. It would, however, be useful if the European legislator could anticipate this and give the necessary elucidation in this area. We see different possible ways forward.

\subsection{A better delineation between Regulation 883/2004 and Directive 2004/38}

A first option would be to do away with all doubts on the relationship between Regulation $883 / 2004$ and Directive $2004 / 38$ by accepting a status of "lex specialis" for the coordination regulation. This would explicitly affirm the current state of EU law and the normal application of Regulation 883/2004. In concreto, this could be effectuated by inserting a safeguarding clause in Directive 2004/38, confirming that the directive does not affect the coordination rules of Regulation 883/2004. Inspiration for such a clause could be found in Article 36(2) of Regulation 492/2011, which provides the following clause in its final provisions: "This Regulation shall not affect measures taken in accordance with Article 48 of the Treaty on the Functioning of the European Union".

In the same line of reasoning, a definition of social assistance could be provided in Directive 2004/38 as neither encompassing SNCBs that were included in Annex X of Regulation $883 / 2004$, nor sickness benefits as provided in Article 3(1)(a) of Regulation 883/2004. This could be done in a general way, by equating "social assistance within the meaning of Directive 2004/38" with "social assistance within the meaning of Regulation 883/2004".

\subsection{Introducing a "flexible residence duration condition" in Regulation 883/2004}


A valid second possibility could be to further clarify the residence concept of Regulation $883 / 2004$ in the context of the relationship between the right to reside and the right to social security benefits in a host Member State, including the right to SNCBs. It can be acknowledged that there is an implicit discrepancy between the perspectives on access to non-contributory benefits in Regulation 883/2004 and Directive 2004/38. The different approaches could be harmonised, whilst still respecting the Treaty obligations with regard to the free movement of persons and more specifically the balance that was struck by the introduction of the special coordination regime for SNCBs.

With regard to the residence concept of Regulation 883/2004 as such, this could be further clarified by giving a promotion to Article 11 Regulation 987/2009. Whereas this is now laid down in the implementing regulation to solve differences of views between institutions of the Member States, it could be transformed from a "reconciliation Article" to a "guiding Article" with regard to the establishment of habitual residence. In concreto, the elements to determine residence that were summed up in Article 11 could be incorporated in the definition of residence in Article $1(j)$ of Regulation 883/2004. This would enhance the visibility and strength of the residence concept of the coordination regulation. Further reflections could be undertaken to better define this habitual residence, for instance by integrating new factual elements that should - deriving from daily practice on the national level - certainly be taken into account when assessing the residence situation of a person.

In order to reconcile the residence concept of Regulation 883/2004 with EU residence law, a modified concept of residence could be adopted for the application of the special coordination regime of the SNCBs by introducing a waiting period before the person is entitled to such benefits in the host Member State. A first period of "residence" within the meaning of Directive 2004/38 could possibly not be considered as "residence" within the meaning of Article $1(\mathrm{j})$ of Regulation 883/2004, since the link with the host Member State could be considered as too weak. A person without a link to the employment market of this State and without any family or other private ties there, should in principle not be considered as resident in that State in this first period.

It could for instance be clarified that during the first three months of "residence" within the meaning of Directive 2004/38, a person is not considered resident yet in the host Member State within the meaning of Regulation 883/2004, "unless this person can prove the opposite". This last addition - which opens the possibility to provide proof of a genuine link with the host Member State - is important, given the need to take into account the principle of proportionality when restricting the free movement of Unions citizens, as already described above. The choice for a monolithical and dominant residence duration requirement of 3 months without the possibility to demonstrate that the person has a 
genuine link with the host Member State, would ignore this fundamental principle of Union law. An overall assessment of all the facts of the individual case should still be required in order to possibly overrule the waiting period.

However, if such a waiting period would be introduced, the persons concerned should be considered as having kept their centre of interest, ergo, their residence in the Member State of origin during this first period. The latter would thus still be the competent State as to the entitlement to SNCBs. If this necessary corollary of postponing the establishment of residence in a Member State would be omitted, such a new regime for SNCBs would without doubt fall foul of the fundamental right to free movement as guaranteed by the Treaties and of the main aim of social security coordination, namely to prevent migrant persons from falling between two stools. More specifically, if the balance sought in the special coordination regime for $\mathrm{SNCBs}^{75}$ is broken by a waiting time period, this fracture has to be compensated by a responsibility for the Member State of origin of the person concerned. Under the auspices of EU social security coordination, the protection of social security rights in the various Member States is the all embracing target to which each single provision in the coordination framework is committed.

Such an approach would have the benefit of respecting the principles of the coordination system as well as the ECJ's "genuine link" case law, whilst also meeting the concerns of the Member States with relation to the transitional coverage of non-active persons. Furthermore, such a three months period would also correspond to the social assistance exception of Article 24(2) of Directive 2004/38.

\subsection{Introducing a new "cost compensation mechanism" in Regulation 883/2004}

An alternative option would be to keep the residence concept as it is now incorporated in Regulation 883/2004, but to seek for a better sharing of the burden amongst the Member States when non-active persons are concerned. Such burden sharing could be accomplished by retaining the responsibility for these persons in the Member State of origin via a cost compensation mechanism. The latter would in this constellation still be financially responsible for the migrating non-active person for a certain period of time (e.g. a period of 3 months). During this first period of residence, the institutions of the host Member State would consequently provide the SNCBs in accordance with its legislation on behalf of the institution of the Member State of origin, which would be obliged to fully reimburse the costs incurred by the host Member State.

75 Here we must repeat that this balance was accepted in order to avoid the obligation to export SNCBs. 
It suffices to say that comparable measures could be taken with regard to equal access of non-active persons to sickness benefits delivered by the competent Member State of residence.

\subsection{A better focus on the establishment of residence in a Member State}

A fourth way forward that should be given specific attention in any way is the organisation of an enhanced control on the establishment of residence in the Member States for the application of Regulation 883/2004. It should be further investigated how the administrative cooperation between the Member States in the framework of the coordination system can contribute to a sound assessment of precarious residence situations and especially to avoiding fraud and abuse, to which is often referred in the general and more colloquial terms of "benefit tourism" or "social tourism".

In this regard, it is not easy to identify a change of residence in practice. Freedom of movement within the European Union allows Union citizens and their families to spend their lives simultaneously in different Member States and to stay there for a shorter or longer period. Under these circumstances, the concept of residence - which is based on the idea that each individual finds her or his centre of activities at one place - becomes problematic. It is difficult to interpret and to examine the residence situation. From this follows that a change of residence should only be accepted if somebody transfers the centre of her or his activities definitely and without any persisting links to the previous Member State of residence.

It is acknowledged that one has to be very careful with the use of those concepts in EU law, as they have always been interpreted very narrowly by the ECJ. There is no abuse where EU citizens and their family members obtain a right of residence under Union law in a Member State other than that of the EU citizen's nationality as they are benefiting from an advantage inherent in the exercise of the right of free movement protected by the Treaty, ${ }^{76}$ regardless of the purpose of their move to that State. ${ }^{77}$ However, both the ECJ and the Commission define abuse as "an artificial conduct entered into solely with the purpose of obtaining the right of free movement and residence".$^{78} \mathrm{~A}$ residence which in actual fact is a "fake residence" (cf. the problems mentioned with regard to "addresses of

76 Case C-212/97 Centros ECR [1999] I-1459, para 27 and Case C-147/03 Commission v Austria ECR [2005] I5969, paras 67-68.

77 Case C-109/01 Akrich ECR [2003] I-9607, para 55 and Case C-1/05 Jia ECR [2007] I-0001, para 31.

78 One should keep in mind that, when the freedom of movement was extended from the economically active to the economically non-active population in the context of Union citizenship, there was a political agreement, that freedom of movement should not be extended to economically non-active persons who take the freedom of movement as a means to get the highest possible social benefit. The idea was to deprive those citizens from the right to free movement, if they intend to change residence driven by the mere motive to get more social benefits. 
convenience") would fall under such a concept of abuse. This of course cannot create rights under EU law.

Article 35 of Directive 2004/38 could be of importance in such cases, as it provides that Member States may adopt the necessary measures to refuse, terminate or withdraw any right conferred by this directive in the case of abuse of rights or fraud, such as marriages of convenience. An "address of convenience" could be treated in the same way and could consequently lead to the refusal, termination or withdrawal of the right to reside in a host Member State. A similar provision could be incorporated in Regulation 883/2004 with regard to residence within the meaning of Article $1(\mathrm{j})$ of Regulation 883/2004.

The ambivalent relationship between Regulation 883/2004 and Directive 2004/38 could be further clarified by:

- a safeguarding clause for Regulation $883 / 2004$ or a definition of social assistance in Directive 2004/38

- a flexible waiting period in the residence concept of Regulation 883/2004 for the application of the special coordination regime for SNCBS

- a cost compensation mechanism between the former Member State of residence and the new State of residence for residence based benefits (SNCBs, sickness benefits) granted to non-active persons

- an enhanced focus on the assessment of the establishment of residence in the Member States in order to prevent confusion and cases of fraud and abuse and the introduction of an "abuse of rights" clause with regard to the residence concept in Regulation $883 / 2004$ 